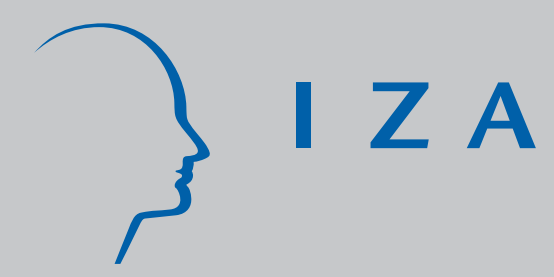

IZA DP No. 1724

Institutions, Markets and Men's and Women's

Wage Inequality: Evidence from Ukraine

Ina Ganguli

Katherine Terrell

August 2005 


\title{
Institutions, Markets and Men's and Women's Wage Inequality: Evidence from Ukraine
}

\author{
Ina Ganguli \\ Harvard University \\ Katherine Terrell \\ University of Michigan, Ann Arbor \\ and IZA Bonn \\ Discussion Paper No. 1724 \\ August 2005
}

IZA

P.O. Box 7240

53072 Bonn

Germany

Phone: +49-228-3894-0

Fax: +49-228-3894-180

Email: iza@iza.org

Any opinions expressed here are those of the author(s) and not those of the institute. Research disseminated by IZA may include views on policy, but the institute itself takes no institutional policy positions.

The Institute for the Study of Labor (IZA) in Bonn is a local and virtual international research center and a place of communication between science, politics and business. IZA is an independent nonprofit company supported by Deutsche Post World Net. The center is associated with the University of Bonn and offers a stimulating research environment through its research networks, research support, and visitors and doctoral programs. IZA engages in (i) original and internationally competitive research in all fields of labor economics, (ii) development of policy concepts, and (iii) dissemination of research results and concepts to the interested public.

IZA Discussion Papers often represent preliminary work and are circulated to encourage discussion. Citation of such a paper should account for its provisional character. A revised version may be available directly from the author. 


\title{
ABSTRACT
}

\section{Institutions, Markets and Men's and Women's Wage Inequality: Evidence from Ukraine*}

\begin{abstract}
Ukraine, the second largest country in the former Soviet bloc, is facing the challenge of rallying popular support for major structural reforms. As in most developing economies, the "Orange Revolution" government's success will depend on its ability to keep income distribution within an acceptable range. This paper is the first to make use of recent methodological developments in Lemieux's (2002) decomposition method to advance our understanding of the determinants of wage inequality in developing and transition economies. With an eye toward future policy, we apply this approach to the first large longitudinal micro data set for Ukraine - the Ukrainian Longitudinal Monitoring Survey (ULMS) - to determine the extent to which the introduction of markets and new institutions affected men's and women's wage inequality between 1986 and 2003. We find that wage inequality rises substantially for both men and women. Applying the Lemieux method, we show that market forces drive the increase in inequality through changes in wage premiums, but the changes in the composition of the labor force (selection) generally contribute to a reduction in wage inequality; the exception is that changes in women's labor composition contribute to an increase in inequality in the top half of their wage distribution. Finally, changes in unobservable characteristics work toward increasing inequality for both men and women. The institution of the minimum wage plays an important role in lowering the growth in inequality, more for women than for men. Going forward, if the government wants to ameliorate the effects of market forces on wage inequality, it should recognize the importance of maintaining the value of, and compliance with, the minimum wage.
\end{abstract}

JEL Classification: $\quad$ C14, I2, J16

Keywords: gender, inequality, semi-parametric estimation, transition, wages, Ukraine

Corresponding author:

Katherine Terrell

University of Michigan Business School

701 Tappan Street, 7th Floor

Ann Arbor, MI 48109

USA

Email: terrell@umich.edu

\footnotetext{
* The authors would like to thank Kathryn Anderson, Olivier Deschenes, John DiNardo, Yuriy Gorodnichenko, Jennifer Hunt, David Margolis, Andrew Newell, and Jan Svejnar for their comments as well as participants of the ACES session at the ASSA meetings in Philadelphia, Jan. 6-9, 2005, the EBRD/IZA Conference in Bologna, May 5-6, 2005 and the SOLE-EALE meetings in San Francisco, June 2-5, 2005. Katherine Terrell is grateful to the NSF (Research Grant SES 0111783) for its generous support. Ina Ganguli appreciates the support of the U.S. Fulbright Program and the EERCEROC at the National University "Kyiv-Mohyla Academy." We also thank Joseph Green, Olga Kupets, and Bogdan Prokopovych for their assistance.
} 


\section{Introduction}

There has been great interest in examining the changes in the structure and dispersion of wages brought about by the transition to market economies in the countries of Central and East Europe (CEE) and the Former Soviet Union (FSU). ${ }^{1}$ Similar interest has arisen with respect to the traditional developing economies as they carried out major privatization, liberalization and other market-oriented reforms over the last two decades. The introduction of market forces was expected to change the structure of wages and the composition of production across economic sectors. $^{2}$ It was not clear, however, how these changes would affect the relative wage inequality of men and women. Would changes in the demand for labor resulting from market forces and the introduction of private ownership result in compositional changes that would increase or decrease women's inequality more than men's? Would the introduction of more flexibility in the labor market (e.g. allowing unemployment and part-time work) and concurrent shifts in labor supply result in more or less wage inequality? Would changes in institutions, such as the minimum wage, affect wage dispersion, and would they affect it differently for men than for women?

Recent methodological advances, namely the development of the DiNardo, Fortin and Lemieux (1996) and Lemieux (2002) decomposition techniques, present new opportunities for answering the above questions. In this paper, we provide the first application of the Lemieux (2002) decomposition in the context of the developing and transition economies. We examine changes in the distribution of wages for men and women in Ukraine, which with a population of 47 million, is the second largest country in the former Soviet bloc and is comparable in population size to Poland and South Africa. Until recently, there has been little global attention given to Ukraine, but the events of the Orange Revolution in late 2004 have put the country on

\footnotetext{
${ }^{1}$ See for example, Keane and Prasad (2002), Münich, Svejnar and Terrell (2005a), Newell (2001), Newell and Socha (2005) for studies of changes in the wage structure in the transition countries and Milanovic (1999) and Atkinson and Micklewright (1992) for studies of changes in inequality in these economies.

${ }^{2}$ In the CEE and FSU countries, the highly compressed wage grids with relatively low returns to higher education under communism led to the expectation that the wage structure would become more dispersed as returns to human capital rose and more skilled individuals took advantage of new opportunities.
} 
center stage of the East-West political theater. The citizenry has shown a desire to break away from Russia and create an independent democratic state with a market-oriented economy. Western nations are clearly interested in helping the country succeed in these goals. Failure could have negative repercussions for the European Union and the United States if Ukraine turns more toward the East and becomes entrenched in corruption and “crony capitalism.” A key factor in enabling the Orange Revolution government to maintain voter support to continue reforms is increasing wage levels and keeping the distribution of income within an acceptable range. $^{3}$

In carrying out our analysis, we examine whether Ukraine’s experience with changes in inequality is similar to that of Russia or whether it is closer in this respect to the CEE models of transition. There is substantial evidence that over the transition period Russia experienced larger declines in real wages and higher rates of growth in wage inequality in comparison to the countries of CEE. ${ }^{4}$ The CEE governments were more likely than those in FSU to use policies that limit the negative forces of the market on vulnerable individuals' incomes. For example, Boeri and Terrell (2002) highlight the much larger share of government expenditures on social safety nets and higher unemployment benefits in the CEE countries as compared to the FSU. ${ }^{5}$ In this paper we will examine a key incomes policy - the minimum wage - which has received less attention in the literature on wages and inequality in the transition economies, but has been deemed important in the US. Minimum wage laws are generally believed to have little or no effect in the FSU countries, where minimum wages have been allowed to erode with inflation to

\footnotetext{
${ }^{3}$ The view that short-term negative distributional consequences can stall economic reform has been in the literature for a while (see e.g., Przeworski, 1991). Recently Kim and Pirttila (2003) have strong evidence to show that public support for reform is negatively correlated with increases in income inequality and positively correlated with economic stability. They use Eurobarometer survey data from post-communist countries from 1990 to 1997 and take into account endogeneity of support for reform and the progress of reform in the econometrics.

${ }^{4}$ See Boeri and Terrell (2002) for a description of this pattern.

${ }^{5}$ Garner and Terrell (1998) show how changes in policies - i.e., targeting welfare benefits and indexing pensions -- in the Czech Republic kept household income inequality from growing significantly in the first years of the transition while a similar study by Commander et al. (1999) show that the lack of indexing of pension benefits contributed significantly to the widening of household income inequality in Russia.
} 
miniscule levels, but their effect is expected to be greater in CEE countries. ${ }^{6}$ Interestingly, Ukraine raised its minimum wage substantially in the late 1990s and one could possibly observe a significant effect on wage inequality.

Lack of good micro data has prevented research on many important economic questions in Ukraine. We are among the first papers to use new household data from the 2003 Ukrainian Longitudinal Monitoring Survey (ULMS), with current (2003) and retrospective (1986) information on over 8,500 individuals. We use these data to answer the following questions: a) To what extent did men's and women's wage inequality rise? b) How much of the rise in inequality is due to changes in the composition of the labor force v. changes in the structure of wages (returns to human capital and job characteristics) brought about by the transition to a market economy? c) To what extent did minimum wages play a role in upholding wages and lowering inequality in Ukraine's transition? For each of these questions we are interested in the changes from the planned economy period (1986) to a period when markets were wellestablished and the government had introduced numerous reforms in its institutions (2003).

The paper is structured as follows: the salient features of Ukraine's policies in the transition are highlighted in Section 2. A description of the data is found in Section 3. Section 4 shows the extent to which inequality rose for men and women and the role of minimum wages in these changes over time. The counterfactual and decomposition analysis is found in Section 5. Section 6 identifies which changes in the composition of the labor forces (covariates) and in the returns to human capital and job characteristics (coefficients) were most important. Section 7 concludes.

\section{Macroeconomic and Institutional Context}

At the time of our first observation, 1986, Ukraine’s economy was characterized by many of the same features found in other countries of the FSU and CEE. It was largely based on heavy

\footnotetext{
${ }^{6}$ See for e.g., Vaughan-Whitehead and Standing (1995) for a description of minimum wages in transition economies.
} 
industry and agriculture; agriculture accounted for almost 25 percent of the total labor force, and 39 percent of the industrial labor force consisted of military-industry (EIU, 1994). As in other Soviet Republics, there was no official unemployment and wages were determined by a centralized tariff or wage grid, leaving little room for employers to determine compensation. ${ }^{7}$ As this was the first year of perestroika, some of the rigidity of the wage system was loosened while Gorbachev tried to spur growth by decentralizing parts of the economy. But wage reforms were introduced only in the non-service sector and the reform was limited: enterprises were required to finance wage increases that were still centrally-mandated (Chapman, 1991).

After Ukraine gained independence from the Soviet Union in 1991 it began a gradual transition to a market economy, rather than the "shock therapy" approach taken in many other countries in the region. For example, price liberalization began in 1992 but it was not completed until 1995. The privatization process was initiated in 1992 and it was still not completed by 2003. From 1992-1994, 1,240 medium and large enterprises were privatized through buyouts by managers and employees but the mass privatization program only began in 1995 and by 2002, the largest enterprises still remained to be privatized (Elborgh-Woytek and Lewis, 2002).

There were a number of wage reforms between 1991 and 2003. The first reform (in the Law on Enterprises of April 1991) abolished the centralized system of wage determination and gave enterprises autonomy to determine wage levels and payment systems. However, they were required (according to Article 19) to use the tariff system as a benchmark to ensure wage differentials between workers according to profession, skill, complexity and conditions of work. In May 1995 a new Law on Wages was adopted, which strengthened the role of bargaining in setting wages and salaries (ILO, 1998) and by 2003 there was a fairly well established market based system for determining wages.

\footnotetext{
${ }^{7}$ The centralized tariff system consisted of wage coefficients by grade that took into account experience, education, and working conditions. See Münich, Svejnar and Terrell (2005b) for a description of the Communist wage grids in Czechoslovakia.
} 
Minimum wage legislation existed throughout the period of our study. In a 1976 law, the official minimum wage in the Soviet Union was set at 70 rubles per month. The eleventh FiveYear Plan (covering 1981-1985) gradually raised the minimum wage to 80 rubles per month by 1985, which is the minimum wage we use at the first date of our analysis. The first Ukrainian minimum wage was established in the 1992 Decree on Wages. It was set according to the price of a basket of goods needed for subsistence, along with "the political discretion to set a higher rate that acted as the floor to wages paid to the lowest occupational grade in any enterprise" (World Bank, 1996). In 1992 the minimum wage was revalued several times due to hyperinflation; however, from 1993 to early 1996, its nominal level remained constant (at 60,000 karbovanets a month). In 2003 it was set at 185 hryvnas a month (approximately \$34.69)

As seen in Figure 1, the minimum wage fell significantly relative to the average wage from 1989, when it was over 30 percent of the average wage, until 1994, when it was less than 5 percent. After this it rose each year and by 2003 it amounted to about 40 percent of the average wage. (Clearly, the measured effect of the minimum wage on salaries and wage inequality in Ukraine would vary significantly depending on which years were selected for the analysis.)

As with most of the former Soviet republics, Ukraine has had a difficult transition process. As Figure 1 shows, GDP declined dramatically at annual rates as high as 20 percent until the mid-1990s, and inflation reached over 10,000 percent during 1992. Real wages were halved in this year. Independent Ukraine experienced economic growth for the first time in 2000. Despite the declines in GDP and hyperinflation, employment in Ukraine decreased very little, a pattern seen in other FSU countries. ${ }^{8}$ Although the official registered unemployment rates as reported by the National Bank of Ukraine remained very low, at less than 1 percent until 1996, the ILO estimates are higher, at over 12 percent in the 1999 and 2000. Partial unemployment (forced leaves and shorter working hours), and informal activity has been common, and many Ukrainians have also begun migrating to gain work abroad.

\footnotetext{
${ }^{8}$ See Boeri and Terrell (2002).
} 


\section{Data}

The data source is the first wave of the Ukrainian Longitudinal Monitoring Survey (ULMS), administered from April 11 until June 30, 2003. The ULMS is the first nationally representative longitudinal survey of Ukrainian households, with a large sample of 4,056 households and 8,621 individuals. In addition to demographic information on each member of the household, the survey contains retrospective data on the characteristics of the jobs held by each member of the household in 1986, 1991, and during 1997-2003. We use the information on both the workers' demographic characteristics and the characteristics of their main job.

For this analysis, we created two cross sections (1986 and 2003) of individuals ages 1556 who reported a monthly salary and were working full time (between 30 and 80 hours per week). ${ }^{9}$ The time points chosen for the analysis capture the pre- and post-transition economic environments. In 1986, perestroika policies had not yet taken hold and in 2003, most stages of economic reform (price liberalization, privatization, and macroeconomic stabilization) were complete and market forces were driving the economy.

Since the 1986 data are obtained retrospectively, questions arise with respect to a) the representativeness of this cross-section, especially in terms of the demographic structure; and b) the accuracy of the data (recall error). The data contain weights to make the 2003 nationally representative, but since the oldest individuals surveyed in 2003 are 72 years old, they would have been 56 years old 16 years earlier. Hence, in order to keep the data comparable in both years, we trim the 2003 data to 56. However, survival bias is more general than this; it means we have fewer individuals in older age groups in the 1986 population. Hence, we follow Gorodnichenko and Sabirianova Peter (2004) and weight the 1986 sample using weights created from information on the age and gender structure from the 1987 Statistical Yearbook of the

\footnotetext{
${ }^{9}$ We restrict the sample to full-time work (40 hours/week) in the 2003 sample since there was virtually no part-time work during Soviet times. We also include individuals working 30 hours/week if they report that this is considered full-time at their job, since this is the case for several professional occupations. We do not include individuals who reported working more than 80 hours per week, due to potential misreporting.
} 
USSR. (We found the regional distribution of the sample weighted 1986 data to be representative of the 1987 regional demographic information, and hence there was no need to re-weight on the regional dimension.) With respect to recall error, it can be argued that people may have had difficulty remembering their wages and employment status 16 years earlier. However, we expect the recall error to be relatively small since 1986 was the year of the Chernobyl nuclear explosion, which most Ukrainians remember vividly. Studies have shown that respondents are less likely to have recall lapse when they have an important event as a reference point. Moreover, since wages set in the communist grid were clearly defined and did not change much over time, we expect them to be more easily remembered. ${ }^{10}$

The wage data are taken from a ULMS question on "net contractual monthly salary” for a main job in December 1986 and 2003. ${ }^{11}$ We rescale the wages for each year so that the mean log wage is zero. Similar to Russia, Ukraine had a significant problem with wage arrears. However by the time of our survey, lack of payment of wages was less frequent than it had been earlier: 10.4 percent of the workers in our sample reported having wage arrears in 2003. This share was higher for men (12.1) than for women (8.8). Nevertheless, by using data from the "net contractual monthly salary,” the problem of wage arrears does not affect our analysis of inequality. ${ }^{12}$

Finally, we only analyze the data of individuals with non-zero monthly salary data. We do not adjust the salary data for hours worked per month since we include only full-time workers. If individuals reported a wage of zero or did not provide salary data, they are not

\footnotetext{
${ }^{10}$ We also note that since we use the self-reported wage as a dependent variable rather than as a regressor, we avoid the usual problem of "errors in variables" with respect to the right hand side variables.

${ }^{11}$ Net contractual salary does not include taxes and it also does not include in-kind payments, arrears, etc. We are not excluding much information by concentrating on the main job since only approximately 2 percent of the 1986 and 2003 samples reported having a second job.

12 Lehmann, et al. (2003) develops counterfactual wage densities for Russia, which provide the distribution of wages in the absence of wage arrears. The ULMS data makes it possible to compare the "actual salary received" with the "contractual salary." As shown in appendix Figure A1, the actual is more than the contractual for individuals at the extreme lower end of the wage distribution, somewhat lower than the contractual for individuals at the extreme upper end, and mixed in the middle of the distribution. Moreover, the differences are is very small, such that there is no correlation between the contractual salary and the difference between the contractual and actual.
} 
included in the sample. Exclusion of these groups will lower inequality from what it would have been since a) those who are part-time workers tend to have lower wages; b) those who are out of the labor market, and hence do not report a wage, tend to be from the lower end of the wage distribution; and c) those who do not respond to the salary question are most likely at the upper tail of the distribution. Brainerd (1998) reports that in Russia, wages in the upper tail of the wage distribution may be underreported due to "innovative schemes" to evade taxes or "under the table' or 'in the envelope' wage payments. ${ }^{13}$ This is also likely to be the case in Ukraine.

We consider both demographic characteristics and job characteristics in our analysis. The demographic variables include age, nationality, and education. The education variable is coded as the highest level completed. Due to the nature of the Soviet and Ukrainian educational systems, individuals with the same number of years of schooling may have different skills and educational attainment. Using the highest degree completed allows returns to vary by the type of attainment. The education levels are defined as: less than High School, High School (through grade 11), Vocational (Technical Education), Secondary Professional (two additional years after High School), University and higher (Bachelor/Specialist/Masters/PhD). The job characteristic variables include location (Kyiv or outside of Kyiv) and activity of the enterprise (at the one digit level of the ISIC).

Table 1 reports summary statistics of these variables for the 1986 and 2003 weighted samples of men and women. It shows the distinct compositional changes in the wage-earning population, which we will discuss further below. Briefly, the demographic structure changed substantially with respect to age and education but not much in terms of nationality. The change in the structure of jobs - i.e., differences in the shares by activity of enterprise, location, and ownership type - reflect changes occurring in other transition countries. Most notably, the share of workers in agriculture and industry decreased, while the shares in service activities rose. Among men, the sector with the greatest increase in jobs was in the transportation and

${ }^{13}$ Brainerd (1998) mentions practices such as paying employees life insurance payments rather than wages or compensating workers with non-monetary benefits. 
telecommunication sector, while among women the greatest increase was in the education, health, and social protection. There was a shift in jobs toward the capital city of Kyiv by 2003, especially for women.

\section{Changes in the Distribution of Wages and the Role of the Minimum Wage}

To address the question of how much change there was in the male and female wage distributions from 1986 to 2003, we plot kernel density estimates of actual wages normalized to zero in each of the two years and calculate several measures of wage dispersion: standard deviation, Gini coefficient, Theil index, and three quantile measures (e.g. the 10-90 differential, or the difference between the $10^{\text {th }}$ and $90^{\text {th }}$ percentile of the log wage distribution). Each of the overall measures differs in its sensitivity to income variations at different points of the distribution. For example, for equi-distant transfers, the Theil measure is more sensitive to transfers at the top of the distribution while the Gini index is considered to be more sensitive to transfers around the mode.

In Figure 2, we present the kernel density estimates of the log of real wages in 1986 and in 2003 for the entire population (Panel A) and for men and women (Panel B). ${ }^{14}$ They show that the distributions of real wages for all workers in 2003 relative to 1986 lost mass in the middle and gained mass in the lower and upper parts. The small gain at the upper end is disappointing given the expectations from reform, but perhaps not surprising given that Ukraine's economy only began to grow in the year 2000. The shapes and positions of the men's and women's distributions (Panel B) are strikingly different in both years. The shape of the women's wage p.d.f. changed from being broad in the middle in 1986 to peaking at the minimum in 2003 whereas the men's distribution changed from being narrowly peaked at the middle to being broader, and with more mass at the lower part of the distribution. ${ }^{15}$

\footnotetext{
${ }^{14}$ The selected halfwidth of the kernel, or the width of the density window around each point, is 0.09 .

${ }^{15}$ Our results differ from the findings of Brainerd (1998) for Russia during the early transition period (1991-1994) in that she finds the changes for women were more equal throughout the distribution, with the bottom widening more than the top. The differences could be due to a number of reasons. It is
} 
The truncation at the left of the distribution is notable in both panels of Figure 2. We have demarcated the 2003 and 1985 minimum wages in each of the figures and it appears that the spikes in the distributions correspond roughly to these wages. The 2003 minimum wage of 185 Hryvnia per month (normalized log value of -0.495) is only slightly higher in the distribution than the 1985 minimum wage of 80 rubles per month (normalized log value of -0.613). The spike in the 2003 distribution (for all workers as well as for men and women separately) is just slightly below the minimum wage in that year, while the spike in the 1986 distribution is slightly above the 1985 minimum wage and close to 90 rubles.

What is especially notable is that: a) the density at these spikes for women is more than double that of men's in both years, and b) the spike near the minimum is much larger, for both men and women, in 2003 than in 1986. These findings indicate how much more important the minimum wage is for women and how much more important the minimum wage is in acting as a wage floor in 2003 than in 1986. The women's wage distribution especially collapses to the minimum wage in 2003. ${ }^{16}$

As seen in Table 2, the rise in overall wage inequality in Ukraine from 1986 to 2003 was significant. The standard deviations of wages (overall) rose by 10.2 percentage points and the Gini and Theil coefficients rose by 4.3 and 4.6 percentage points, respectively. According to our analysis, the Gini coefficients in Ukraine did not rise as much as the estimates for Russia from numerous sources (e.g., the UNU/WIDER World Income Inequality Database, WIID). Men’s overall wage inequality is higher than women's in each year, but we cannot conclude that overall inequality rose more for men v. women, counter to recent studies of Poland (Keane and Prasad, 2005) and Russia (Brainerd, 1998). We find different results among the six measures of inequality over this period in Ukraine. More precisely, changes in the standard deviations, the 10-90 and the 10-50 quantile measures indicate that men's inequality rose more than women's,

possible that the minimum wage, which had deteriorated in this period, was not truncating the distribution in Russia. It may also be due to the fact that unlike our sample, hers is not restricted to full-time workers.

${ }^{16}$ In 1986 the minimum wage is 58.8 percent of women's average wage and it rises to 70.5 percent in 2003. 
but the reverse is true for the Theil and 50-90 measures. Men experienced a larger widening in the bottom half as compared to the top, whereas we find the opposite pattern for women: dispersion in the bottom half actually fell, while dispersion grew in the top half. Moreover, the growth in the top half of the distribution was much larger for women than for men.

\section{Determinants of Changes in Inequality: Counterfactual and Decomposition Analysis}

\subsection{Methodology}

To understand which factors within market forces are more important in accounting for the changes in men's and women’s inequality, we use Lemieux’s (2002) methodology. Lemieux (2002) builds on work by Juhn, Murphy, and Pierce (1993), henceforth JMP, and DiNardo, Fortin, and Lemieux (1996), henceforth DFL, to develop a methodology that allows the construction of counterfactual wage distributions and their decomposition into three components:

1) labor force composition, i.e., the covariates (Xs), 2) the prices of human capital and job characteristics, i.e., regression coefficients $(\beta s)$, and 3) residuals $(\mu s)$.

We begin by constructing a counterfactual wage distribution that would prevail in period $t=2003$ if the distribution of observable worker characteristics were the same as in period $s=$ 1986, based on DFL The method essentially modifies the classical kernel density estimator by attaching new sample weights, $w_{i t}^{a}$, to each observation in the place of the original sample weights, $w_{i t}$, which are used to compute sample statistics representative of the population, where $\sum w_{\text {it }}=1$. To construct $w_{i t}^{a}$, we first estimate propensity scores with a logit model using pooled $t$

and $s$ period data from the ULMS. The propensity score is the probability that an individual in the pooled sample comes from the period s sample conditional on $x$ :

$$
p_{i s}=\operatorname{Prob}\left(\text { period }=s \mid x_{i s}\right) \text {. }
$$

The re-weighting factor $\Psi_{i}$ is then computed from the propensity scores as

$$
\Psi_{i}=\frac{\mathrm{p}_{\mathrm{is}}}{1-\mathrm{p}_{\text {is }}} .
$$

The new sample weight is then computed as the product of the original sample weight and the reweighting factor: 


$$
w_{i t}^{a}=w_{i} \Psi_{i}
$$

We can express the counterfactual density of wages -- the density that would have existed in 2003 if the distribution of characteristics of the workers had remained as in 1986 -- as:

$$
f\left(y ; t_{y}=2003, t_{x}=1986\right)=\int w^{a} f\left(y \mid x, t_{y}=2003\right) h\left(x \mid t_{x}=2003\right),
$$

where $\mathrm{y}$ is a vector of wage, $x$ is a vector of individual attributes and $w^{a}$ is the vector of weights.

We next focus on computing the distribution of the counterfactual wage, $y_{i t}^{a}$ that would prevail in period $t$ if the 'price' or 'returns' to the characteristics were the same as in period $s$. We first estimate separate OLS Mincerian wage regression (for men and women) for each period: ${ }^{17}$

$$
\begin{aligned}
& \mathrm{y}_{\mathrm{it}}=X_{\mathrm{it}} \beta_{\mathrm{t}}+\mu_{\mathrm{it}} \\
& \mathrm{y}_{\mathrm{is}}=X_{\mathrm{is}} \beta_{\mathrm{s}}+\mu_{\mathrm{is}}
\end{aligned}
$$

and then, following JMP, compute the counterfactual wage,

$$
y_{i t}^{a}=X_{\mathrm{it}} \beta_{\mathrm{s}}+\mu_{\mathrm{it}} .
$$

Lemieux (2002) shows how a number of counterfactual distributions can be created with JMP's counterfactual wage variable, $y_{i t}^{a}$, and DFL's counterfactual weights, $w_{i t}^{a}$. He also demonstrates how with these counterfactual distributions, it is possible to decompose changes in various distributional measures into changes in each of the three components: $X \mathrm{~s}, \beta \mathrm{s}$ and $\mu \mathrm{s}$. For example, we can decompose changes in the standard deviation using the two counterfactual standard deviations, $\sigma_{03}^{\mathrm{a}}$ and $\sigma_{03}^{\mathrm{b}}$, where the former is the standard deviation of the counterfactual distribution $y_{i 03}^{a}$ (2003 distribution with the $1986 \beta$ s) and the latter is the standard deviation from the counterfactual distribution $y_{i 03}^{a}$ weighted with $w_{i 03}^{a}$ (2003 distribution with $1986 \beta$ s and 1986 distribution of Xs). The change in the actual standard deviation can be decomposed in the following way:

$$
\sigma_{03}-\sigma_{86}=\left(\sigma_{03}-\sigma_{03}^{\mathrm{a}}\right)+\left(\sigma_{03}^{\mathrm{a}}-\sigma_{03}^{\mathrm{b}}\right)+\left(\sigma_{03}^{\mathrm{b}}-\sigma_{86}\right)
$$

17 Both the OLS regression and the logit model use the same set of covariates: demographic characteristics (education levels, age groups and nationality) and job characteristics (activity of enterprise and location of job). 
where the first term on the right is the effect of the changes in the $\beta \mathrm{s}$, the second term is the effect of changes in the distribution of Xs, and the last term is the residual or unexplained portion. The effect of a factor may depend on the ordering of the elements in the decomposition, so we also carry out the decomposition in reverse e.g., $\left(\sigma_{03}-\sigma_{03}^{\mathrm{b}}\right)+\left(\sigma_{03}^{\mathrm{b}}-\sigma_{03}^{\mathrm{a}}\right)+\left(\sigma_{03}^{\mathrm{a}}-\sigma_{86}\right)$.

We plot actual and counterfactual kernel densities estimates of the wages and compute several descriptive and counterfactual distributional statistics, as well as carry out the decomposition and reverse-order decomposition. The findings are described in the next section.

\subsection{Findings}

Figure 3 shows the kernel density estimates for men’s and women’s actual wages in 2003 plus two counterfactuals, i.e., what would have happened to the 2003 distributions if a) the distribution of covariates (Xs) had not changed from $1986,{ }^{18}$ and b) if the 'prices' of the workers' demographic and job characteristics ( $\beta$ s) had not changed from $1986 .{ }^{19}$ The actual 2003 density (solid line) and the hypothetical 2003 density (dashed line) in Figures 3a (men) and 3c (women) indicate that the distributions would have shifted somewhat to the right if men and women had the $\beta$ s of 1986, but it is not clear if this would have increased or decreased inequality. Figures $3 b$ (men) and 3d (women) show that the distributions would have shifted to the left, i.e., lost mass at the higher ends and gained mass at the low end (especially for women), if the measurable job and demographic characteristics in 2003 had been the same as in 1986.

While the kernel densities give us a sense of which factors are more important in driving the shapes in the male and female wage distributions, we can more precisely draw conclusions about their relative impact on changes in inequality from the decompositions of changes in the six measures of inequality. We present counterfactuals and decompositions of four measures of inequality in one order and then in reverse order for men and for women in Tables 3 and 4,

\footnotetext{
${ }^{18}$ This is the distribution of $y_{i 03}$ weighted with $w_{i 03}^{a}$.

${ }^{19}$ This is the distribution of $y_{i 03}^{a}$ weighted with $w_{i}$.
} 
respectively. ${ }^{20}$ We find that both decompositions yield similar findings for men, however for women there are some discrepancies.

These results for men in Table 3 consistently show that the changes in the $\beta$ 's from 1986 to 2003 led to an increase in inequality. Inequality in 2003 would have been between 7 and 10 percent lower for men in 2003 had they been paid with the 1986 wage structure. Conversely, changes in the $\beta$ s contributed to an increase in inequality in 2003. The two decompositions also consistently show that the change in the composition of the labor force (Xs) contributed to a reduction in inequality from what it would have been. In almost all cases the effect of the $\beta$ s is larger than the effect of the Xs. However, the most important component in the rise in inequality is the change in the residuals. One important factor in the residuals most likely increasing wage inequality is privatization. Keane and Prasad (2005) note in their work in Poland that the reallocation of workers from the public sector to the private sector accounts for 40 percent of increased earning inequality there. ${ }^{21}$ However, we cannot include a variable on firm ownership in the counterfactual analysis because of the lack of private firms in 1986.

The results for women in Table 4 are consistent in showing that, unlike for men, the changes in the Xs from 1986 to 2003 contributed to an increase in inequality for the upper half (50-90) of the distribution, and to a decrease in inequality in the lower half (10-50); but they lowered the other two measures of wage inequality from what it would have been had there been no change. The role of the $\beta$ s for women tends to increase inequality, but the signs are not consistently positive across all measures of inequality. In both decompositions, changes in the $\beta$ s appear to increase inequality for the 50-90 measure and the standard deviation, but the signs are inconsistent for the 10-90 and 10-50 measures. Moreover, the findings are not consistent in whether the Xs or $\beta$ s are more important. Finally, as with men, the effect of the residuals ( $\mu$ s) is

\footnotetext{
${ }^{20}$ We are not able to decompose the Gini and the Theil measures with the Lemieux (2002) method, since it relies on the use of log wages.

${ }^{21}$ However, they stress that that the within sector variance accounted for 52 percent of the increase inequality.
} 
the most important factor in explaining the increase in equality. Moreover, the magnitude of the effect of the residuals is very similar for men and women in both decompositions.

\section{Identification of the Changes in the Xs and $\beta s$}

We next try to understand which Xs and which $\beta$ s are more important in the changes in inequality by looking more closely at the coefficients on the logit models used to estimate the propensity scores and the coefficients on the wage regressions used to construct alternative wages.

\subsection{Shifts in the Labor Composition and the Minimum Wage}

It is clear from the logit coefficients and marginal effects presented in Table 5 that men 20-49 years of age, with less than high school education and working in the agricultural and manufacturing sector are more likely to be in the 1986 sample than in the 2003 sample. The women who are more likely to be working in 1986 have similar characteristics: 15-29 years old, Russian, with less than high school education and working outside Kyiv in a job that was not in either transportation, communication and financial services or education health, and social work.

The descriptive statistics in Table 1 supplement our understanding of the relative changes in the composition for men v. women and help us understand why changes in the Xs ameliorated the increase in inequality for men throughout the distribution, but for women decreased it only in the lower half of the distribution, while increasing it in the top half of the distribution. An important factor in this phenomenon is the larger decline in employment (full-time only) among women (34.0 percent) than among men (19.5 percent) over this period. Moreover, whereas the logit results indicate that many of those who left employment were from the lower part of the wage distribution, Table 1 shows that the share of individuals with low wage characteristics fell more for women than for men, i.e., the share of women with less than high school education fell by 14.7 percentage points, while the decline for men was only 7.9 percentage points. Conversely, the share of women with higher education rose by 9.2 percentage points, but for men, this share rose by only 4.2 percentage points. 
Hence, the fact that more educated women represent a larger share in 2003 than in 1986 helps explain why the changes in characteristics worked to increase inequality for women in the upper half of the distribution. The large exit from the workforce of less-skilled women, combined with the binding minimum wage, help explain why inequality fell in the lower half of the distribution for women.

For men, it is also true that those with low wage demographic characteristics were also more likely to exit the labor force; however the declines in their employment were smaller than among low-wage women. The more important reason why inequality in the bottom half of the men's wage distribution grew more than women's is because the minimum wage was not as binding of a constraint for men as for women, since men's wages tended to be higher.

\subsection{Changes in the Structure of Wages}

The results of the human capital earnings regressions for each year for men and women are shown in Appendix Table A1, but our principal interest is in the changes in these coefficients over time for men and for women, which are presented in Table 6. The number of coefficients that change significantly over time, indicative of the degree to which the wage structure changed, is higher for women than men. For example, for women there was a significant change in the wage-age profile over time, while for men there is no change in the wage-age profile.

Changes in the returns to human capital do not appear to be an important factor explaining increasing inequality in Ukraine. Whereas the returns to higher education increased for both men and women in 2003, the 1986-2003 difference is only statistically significant for women in the secondary professional category. Our results are consistent with an earlier study by the World Bank (1996) of Ukraine's wage structure, which also finds that the earnings differentials by education remained very low in the transition, like in Soviet times. Moreover, Gorodnichenko and Sabirianova Peter (2004) have similar findings in their study using the same data set and other time periods. The lack of significance is striking given that the literature on changes in the returns to human capital in transition countries has consistently shown that a factor driving the increase in inequality was the more rapid increase in the returns to higher 
education (e.g. Jolliffe and Campos, 2005; Münich, Svejnar and Terrell, 2005b; Orazem and Vodopivec, 1997; and Rutowski, 1996).

On the other hand, shifts in the inter-industry wage structure are significant for both men and women and are an important factor explaining inequality. The wage premium associated with jobs in any economic activity rose relative to wages in agriculture for both men and women. ${ }^{22}$ This is consistent with the literature for transition economies (see e.g., Adamchik and Bedi, 2000) and with the finding by the World Bank (1996) for Ukraine. Newell (2001) concludes from his study of numerous transition economies that increasing inter-industry wage differentials are a principal cause of increases in wage inequality.

\section{Conclusion}

Recent methodological advances, namely the development of the DiNardo, Fortin and Lemieux (1996) and Lemieux (2002) decomposition techniques, present new opportunities for analyzing the changes in the structure and dispersion of wages that were brought about by the major privatization, liberalization and other market-oriented reforms carried out in transition and other developing countries over the last two decades. In this paper, we provide the first application of the Lemieux (2002) decomposition in the context of the developing and transition economies. We examine changes in the distribution of wages in Ukraine and parse out the effects of markets and the institution of minimum wage.

Ukrainians have experienced a difficult transition to a market-oriented economy, with dramatic declines in GDP and hyperinflation in the 1990s and relatively rapid economic growth since then. In this respect, Ukraine's transition path is similar to that of Russia. Yet, wage inequality has risen much less than in Ukraine than in Russia, an outcome that we attribute to Ukraine's stronger commitment to the institution of the minimum wage and more gradual approach to introducing market forces during the transition.

\footnotetext{
${ }^{22}$ It does not appear however that the differences among the non-agricultural industries are significant, although we have not tested for this.
} 
We find that wage inequality for all workers grew in the top half of the distribution and actually fell in the bottom half from 1986 to 2003. The rise in the top is not as great as may be expected after a decade of reform, but then the economy only began to grow in 2000. The decline in inequality in the lower half of the distribution in 2003 is being driven by changes in women's wage inequality, since men's inequality grew more in the bottom half than in the top half of the distribution. The principal factor explaining why inequality in the bottom half fell is the binding minimum wage for women. Although a large group of men's wages fell in the lower half, not many fell to the level of the minimum wage. This finding regarding the role of the minimum wage is counter to what has been surmised in the literature for the FSU countries. For example, Brainerd (2000; 1998) suggests that the significant widening of the lower half of the distribution in Russia and Ukraine as compared to other transition countries was due to the low and deteriorating minimum wage in these countries. We find that the minimum wage played an important role for women in both 1986 and 2003; although we recognize that its level fell substantially in real terms during the 1990s and may not have played a binding role at that time.

In general, we find that changes in the wage structure brought on by the new market system contributed to the increase in inequality for men (and perhaps for women), while changes in the composition of the work force moderated the increase in inequality (i.e., lowered it from what it would have been had the composition of the work force not changed). The exception is that changes in the composition of the women's labor force increased women's wage inequality in the upper half of the distribution, while it lowered it in the bottom half.

The changes in the values of the explanatory variables (Xs) and the estimated coefficients ( $\beta$ s) carry similar weight in the decomposition, with neither one being as important as the change in the unobservables. The question that arises is which changes in the composition and which changes in returns are more important? The changes in the $\beta$ s that were most significant were those on the activities of enterprises as the changes on returns to human capital (age and education) were not significant for the most part. With respect to composition, we find large changes in the composition of skills and activities of enterprises: the shares of less educated and 
in agricultural and manufacturing activities fell significantly. The large exodus of low wage female workers is consistent with earlier findings by Hunt (2002) for Germany and Newell and Socha (2005) for Poland. As concerns unobservables, we suspect that the privatization process and the minimum wage, neither of which we can capture in the counterfactuals, played an important part.

In concluding, we note that the changes in both the $\beta$ s and Xs were greater for women than for men. Moreover, there was a larger exodus of women than men from the workforce over this period. If one considers the change in inequality as a proxy for the change in welfare, future research should take this exit from labor force into account - for instance by examining consumption in addition to income data. It is possible that employment, even at low wages, might provide higher utility to some individuals than being out of the labor force. From the standpoint of the Orange Revolution government and other governments looking for popular support, this would obviously be an important consideration. Finally, our results indicate that analysts and policymakers in the transition economies should take note of the effect of minimum wages on women. 


\section{References}

Adamchik, Vera and Arjun Bedi, 2000. "Wage differentials between the Public and Private Sectors: Evidence from an Economy in Transition,” Labour Economics, Vol. 7, 203-224.

Atkinson Anthony B. and John Micklewright, 1992, Economic Transformation in Eastern Europe and the Distribution of Income. Cambridge: Cambridge University Press.

Boeri, Tito and Katherine Terrell, 2002. "Institutional Determinants of Labor Reallocation in Transition," Journal of Economic Perspectives, Vol. 16, No. 1: 51-76.

Brainerd, Elizabeth, 2000. "Women in Transition: Changes in Gender Wage Differentials in Eastern Europe and the Former Soviet Union,” Industrial and Labor Relations Review, Vol. 54, No. 1, October: 138-162.

, 1998. "Winners and Losers in Russia’s Economic Transition," The American Economic Review, Vol. 88, No. 5, December: 1094-116.

Chapman, Janet, 1991. “Recent and Prospective Trends in Soviet Wage Determination,” in Guy Standing (ed.), In Search of New Flexibility: The New Soviet Labor Market, Geneva: International Labour Office.

Commander, Simon, Andrei Tolstopiatenko, and Ruslan Yemtsov, 1999. "Channels of Redistribution: Inequality and Poverty in the Russian Transition," Economics of Transition, Vol. 7, No. 2: 411-447.

DiNardo, John, Nicole Fortin, and Thomas Lemieux, 1996. "Labor Market Institutions and the Distribution of Wages, 1973-1992: A Semiparametric Approach,” Econometrica, Vol. 64, No. 5: 1001-1044.

Economist Intelligence Unit, 2003. Country Report: Ukraine, October.

Economist Intelligence Unit, 1994. Ukraine, Belarus, Moldova: Country Profiles.

Elborgh-Woytek, Katrin and Mark Lewis, 2002. "Privatization in Ukraine: Challenges of Assessment and Coverage in Fund Conditionality," IMF Policy Discussion Paper PDP/02/7, May.

Garner, Thesia and Katherine Terrell, 1998 “A Gini Decompositon Analysis of Inequality in the Czech and Slovak Republics During the Transition,” The Economics of Transition, Vol. 6 No. 1: 23-46.

Gorodnichenko Yuriy and Klara Sabirianova Peter, 2004. "Returns to schooling in Russia and Ukraine: A Semiparametric Approach to Cross-Country Comparative Analysis,” Journal of Comparative Economics, Vol. 33: 324-350. 
Hunt, Jennifer, 2002. “The Transition in East Germany: When is a Ten-Point Fall in the Gender Wage Gap Bad News?” Journal of Labor Economics, Vol. 20, No. 1: 148-169.

International Labour Office, Central and Eastern European Team (ILO), 1998. Ukraine Country Employment Policy Review. Geneva.

(ILO), 1995. The Ukrainian Challenge: Reforming Labour Market and Social Policy, Budapest: Central European University Press.

Jolliffe, Dean and Nauro Campos, 2005. "Does Market Liberalization Reduce Gender Discrimination? Econometric Evidence from Hungary, 1986 to 1998.” Labour Economics, 2005, Vol. 12, No. 1: 1-22.

Juhn, Chinhui, Kevin Murphy and Brooks Pierce, 1993. "Wage Inequality and the Rise in Returns to Skill,” Journal of Political Economy, Vol. 101: 410-41.

Keane, Michael and Eswar Prasad, 2005. "Inequality, Transfers and Growth: New Evidence from the Economic Transition in Poland,” The Review of Economics and Statistics, Vol. 84: 324-341.

Kim, Byung-Yeon and Jukka Pirttila, 2003. "Political Constraints and Economic Reform: Empirical Evidence from Post-Communist Transition in the 1990s" unpublished manuscript, Sogang University, Korea.

Lehmann, Hartmut and Jonathan Wadsworth, 2003. "Wage Arrears, Pay Gaps, and the Distribution of Earnings: What can we learn from Russia?” Royal Holloway-University of London Discussion Paper 2003-02.

Lemieux, Thomas, 2002. "Decomposing Changes in Wage Distributions: A Unified Approach,” Canadian Journal of Economics, Vol. 35, No. 4: 646-688.

Milanovic, Branko, 1999. "Explaining the Increase in Inequality during the Transition," Economics of Transition, Vol. 7, No. 2: 299-341.

Münich, Daniel, Jan Svejnar and Katherine Terrell, 2005a. “Is Women’s Human Capital Valued more by Markets than by Planners?” Journal of Comparative Economic, Vol. 33, No. 2:278-299.

, 2005b. "Returns to Human Capital under the Communist Wage Grid and during the Transition to a Market Economy,” Review of Economics and Statistics, Vol. 87, No. 1: $100-123$.

Newell, Andrew, 2001. “The Distribution of Wages in Transition Countries," Institute for the Study of Labor (IZA), Discussion Paper No. 267, March. 
Newell, Andrew and Mieczyslaw W. Socha, 2005. "The Distribution of Wages in Poland, 19922002,” Institute for the Study of Labor (IZA), Discussion Paper No. 1485, February.

Orazem, Peter and Milan Vodopivec, 1997. "Value of Human Capital in Transition to Market: Evidence from Slovenia," European Economic Review, papers and proceedings, Vol. 41, Issue 3-5 : 893-903.

Przeworski, Adam, 1991. Democracy and the Market: Political and Economic Reforms in Eastern Europe and Latin America. Cambridge, UK: Cambridge University Press.

Rutkowski, Jan, 1996. "High Skills Pay Off: The Changing Wage Structure During Economic Transition in Poland,” Economics of Transition, Vol. 4, No. 1, May: 89-112.

Vaughan-Whitehead, D. and Guy Standing (eds.), 1995. Minimum Wages in Central and Eastern Europe: From protection to destitution Geneva: International Labour Organization.

The World Bank, 1996. “Poverty in Ukraine,” World Bank Report No. 15602-UA, June 27.

The World Currency Yearbook, 1986/1987. Brooklyn, NY: International Currency Analysis, Inc. 


\section{Table 1: Policy Timeline}

1985 Beginning of perestroika.

1986 Wage reforms introduced in goods sectors.

1990 Ukrainian Council of Ministers formulates a "Program for Transition to a Market Economy" (Nov.)

1991 Independence from the USSR (Aug.)

Nationalization of all USSR property in Ukraine (Sept.)

Employment Act passes (legitimizes unemployment)

Creation of State Employment Service, Employment Fund

Decentralization of wage system. Tariff system still used as a benchmark to ensure wage differentials.

1992 Initial price liberalization (Jan.)

Small- and large-scale privatization begins

Karbovanets (interim currency) introduced

Reintroduction of centralized system of wage regulation

Decree on Wages establishes minimum wage to be determined by prices of 70 goods needed for ' subsistence."

1993 Income-tax law adopted.

Law on Collective Contracts and Agreements establishes legal grounds for collective bargaining.

General tariff agreement sets wage coefficients for different categories of workers and sectors based on the minimum wage.

1995 Most prices liberalized

Voucher privatization begins

Most export quotas and licenses abolished

New Law on Wages adopted, strengthening the role of bargaining in setting wages.

1996 New currency (Hryvnia) introduced

1999 New "On Subsistence Minimum" law sets a new official minimum consumption basket

2000 Significant reforms introduced in areas of government decision-making, budget, tax, land, and energy sector. ${ }^{2}$ (e.g. Social privileges for certain population and professional groups were reduced in the 2000 State Budget Law.)

Sources: Aslund (2002), EBRD (1999), ILO (1998), ILO (1995), Chapman (1991).

${ }^{1}$ This method was later suspended. Now, the Cabinet of Minister decides the minimum wage, which must be approved by Parliament.

${ }^{2}$ Binding at all levels of contractual regulation of wages, as agreed by the Cabinet of Ministers and twelve trade union associations

${ }^{2}$ See Aslund (2002) for discussion of these reforms. 
Table 2: Changes in the Characteristics of Men and Women Working Full-Time (Using Sample Weights)

\begin{tabular}{|c|c|c|c|c|c|c|c|c|c|c|}
\hline & \multicolumn{5}{|c|}{ Males } & \multicolumn{5}{|c|}{ Females } \\
\hline & \multicolumn{2}{|c|}{1986} & \multicolumn{2}{|c|}{2003} & \multirow{2}{*}{\begin{tabular}{c|}
$2003-1986$ \\
$\Delta \%$
\end{tabular}} & \multicolumn{2}{|c|}{1986} & \multicolumn{2}{|c|}{2003} & \multirow{2}{*}{$\begin{array}{c}2003-1986 \\
\Delta \% \\
\end{array}$} \\
\hline & $\%$ & Obs & $\%$ & Obs & & $\%$ & Obs & $\%$ & Obs & \\
\hline Age & & & & & & & & & & \\
\hline$\%$ 15-19 & 2.17 & 37 & 2.89 & 39 & 0.72 & 3.47 & 79 & 1.47 & 22 & -2.00 \\
\hline$\%$ 20-29 & 36.19 & 609 & 27.44 & 372 & -8.75 & 27.86 & 631 & 19.61 & 293 & -8.25 \\
\hline \% 30-39 & 31.34 & 528 & 24.74 & 335 & -6.60 & 30.60 & 693 & 26.04 & 389 & -4.56 \\
\hline$\% 40-49$ & 18.64 & 314 & 28.42 & 385 & 9.78 & 24.70 & 559 & 34.87 & 521 & 10.17 \\
\hline$\% 50-56$ & 11.66 & 196 & 16.51 & 224 & 4.85 & 13.36 & 302 & 18.02 & 269 & 4.66 \\
\hline \multicolumn{11}{|l|}{ Nationality } \\
\hline \% Ukrainian & 78.19 & 1312 & 77.92 & 1052 & -0.27 & 77.59 & 1745 & 78.46 & 1165 & 0.87 \\
\hline \% Russian & 18.25 & 4 & 17.51 & 236 & -0.74 & 19.20 & 432 & 18.35 & 273 & -0.85 \\
\hline \% Other (Inc. Byelorussian, Jewish) & 3.56 & 60 & 4.57 & 62 & 1.01 & 3.21 & 72 & 3.19 & 47 & -0.02 \\
\hline \multicolumn{11}{|l|}{ Education Levels } \\
\hline \% Less than High School & 12.67 & 213 & 4.79 & 65 & -7.88 & 17.22 & 390 & 2.56 & 38 & -14.66 \\
\hline \% High School & 26.94 & 454 & 22.68 & 307 & -4.26 & 25.80 & 584 & 18.51 & 277 & -7.29 \\
\hline \% Vocational & 29.37 & 495 & 33.40 & 453 & 4.03 & 16.12 & 365 & 22.13 & 331 & 6.01 \\
\hline \% Secondary Professional & 17.97 & 303 & 21.90 & 297 & 3.93 & 26.52 & 600 & 33.31 & 498 & 6.79 \\
\hline$\%$ Higher Education ${ }^{1}$ & 13.05 & 220 & 17.23 & 234 & 4.18 & 14.34 & 325 & 23.49 & 351 & 9.15 \\
\hline \multicolumn{11}{|l|}{ Location } \\
\hline \% Kyiv & 6.04 & 102 & 8.18 & 111 & 2.14 & 5.92 & 134 & 9.70 & 145 & 3.78 \\
\hline \%Other & 93.96 & 1582 & 91.82 & 1244 & -2.14 & 94.08 & 2129 & 90.30 & 1349 & -3.78 \\
\hline \multicolumn{11}{|l|}{ Activity of Enterp } \\
\hline \%Agriculture, Hunting \& Forestry & 17.99 & 301 & 10.39 & 140 & -7.60 & 13.19 & 296 & 7.07 & 105 & -6.12 \\
\hline \%Manufacturing \& Mining & 38.57 & 645 & 31.98 & 430 & -6.59 & 30.42 & 683 & 20.39 & 303 & -10.03 \\
\hline \%Elec, Gas, Water \& Construction & 9.54 & 160 & 14.03 & 189 & 4.49 & 4.67 & 105 & 3.83 & 57 & -0.84 \\
\hline \%Transport, Communic. \& Financial ${ }^{2}$ & 16.59 & 277 & 24.12 & 324 & 7.53 & 18.15 & 407 & 22.69 & 337 & 4.54 \\
\hline \%Public Admin. \& Defense & 5.84 & 98 & 5.73 & 77 & -0.11 & 3.41 & 77 & 4.09 & 61 & 0.68 \\
\hline \%Education, Health \& Social Work & 6.22 & 104 & 7.64 & 103 & 1.42 & 23.56 & 529 & 33.02 & 490 & 9.46 \\
\hline$\%$ Other $^{3}$ & 5.24 & 88 & 6.10 & 82 & 0.86 & 6.61 & 148 & 8.91 & 132 & 2.30 \\
\hline \multirow{3}{*}{ Total Obervations } & & 1684 & & 1355 & $-19.5 \%$ & \multirow{2}{*}{\multicolumn{2}{|c|}{$\frac{2263}{1986}$}} & & 1494 & $-34.0 \%$ \\
\hline & \multicolumn{2}{|c|}{1986} & \multicolumn{2}{|c|}{2003} & $2003-1986$ & & & \multicolumn{2}{|c|}{2003} & 2003-1986 \\
\hline & Mean & Std. Dev. & Mean & Std. Dev. & $\Delta$ Mean & Mean & Std. Dev. & Mean & Std. Dev. & $\Delta$ Mean \\
\hline Mean Age & 34.81 & 10.15 & 37.24 & 10.79 & 2.43 & 36.24 & 10.36 & 39.13 & 10.06 & 2.89 \\
\hline Mean Log Salary & 0.23 & 0.49 & 0.17 & 0.63 & -0.06 & -0.17 & 0.45 & -0.17 & 0.54 & 0.00 \\
\hline
\end{tabular}

${ }^{1}$ Higher Education includes Bachelor, Specialist, Masters or PhD.

${ }^{2}$ Includes Wholesale/Retail Trade, Repair of Motor Vehicles/Motorcycles; Hotels \& Restaurants; Transport, Storage \& Communication; Financial Intermediation, Real Estate, Renting \& Business Activities

${ }^{3}$ Includes Other Community, Social and Personal Service Activities 
Table 3: Levels of Inequality in 1986 and 2003

\begin{tabular}{c|ccc|ccc|ccc}
\hline \hline & \multicolumn{4}{|c|}{ Total } & \multicolumn{3}{c|}{ Men } & \multicolumn{3}{c}{ Women } \\
& 1986 & 2003 & $\mathbf{2 0 0 3 - 1 9 8 6}$ & 1986 & 2003 & $\mathbf{2 0 0 3 - 1 9 8 6}$ & 1986 & 2003 & $\mathbf{2 0 0 3 - 1 9 8 6}$ \\
\hline & & & & & & & & & \\
Std. Dev. & 0.508 & 0.610 & $\mathbf{0 . 1 0 2}$ & 0.492 & 0.625 & $\mathbf{0 . 1 3 3}$ & 0.445 & 0.542 & $\mathbf{0 . 0 9 7}$ \\
$10-90$ & 1.322 & 1.420 & $\mathbf{0 . 0 9 8}$ & 1.253 & 1.540 & $\mathbf{0 . 2 8 8}$ & 1.076 & 1.168 & $\mathbf{0 . 0 9 1}$ \\
$10-50$ & 0.629 & 0.545 & $\mathbf{- 0 . 0 8 4}$ & 0.588 & 0.758 & $\mathbf{0 . 1 7 0}$ & 0.470 & 0.357 & $\mathbf{- 0 . 1 1 3}$ \\
$50-90$ & 0.693 & 0.875 & $\mathbf{0 . 1 8 2}$ & 0.665 & 0.783 & $\mathbf{0 . 1 1 8}$ & 0.606 & 0.811 & $\mathbf{0 . 2 0 5}$ \\
Gini & 0.291 & 0.333 & $\mathbf{0 . 0 4 3}$ & 0.282 & 0.328 & $\mathbf{0 . 0 4 7}$ & 0.251 & 0.299 & $\mathbf{0 . 0 4 8}$ \\
Theil & 0.146 & 0.192 & $\mathbf{0 . 0 4 6}$ & 0.135 & 0.181 & $\mathbf{0 . 0 4 6}$ & 0.108 & 0.165 & $\mathbf{0 . 0 5 8}$ \\
\hline \hline
\end{tabular}


Table 4: Decomposition of Changes in Inequality for Men and Women

\begin{tabular}{|c|c|c|c|c|}
\hline & \multicolumn{4}{|c|}{ Men } \\
\hline & Std. Dev. & $10-90$ & $10-50$ & $50-90$ \\
\hline 1) 2003 & 0.625 & 1.540 & 0.758 & 0.783 \\
\hline 2) 2003 with $1986 \mathrm{~B}$ & 0.581 & 1.429 & 0.701 & 0.727 \\
\hline 3) 2003 with $1986 \mathrm{~B} \& \mathrm{X}$ & 0.605 & 1.471 & 0.742 & 0.728 \\
\hline 4) 1986 & 0.492 & 1.253 & 0.588 & 0.665 \\
\hline 5) 2003 - 1986 Difference & 0.133 & 0.288 & 0.170 & 0.118 \\
\hline \multicolumn{5}{|l|}{ Effect of: } \\
\hline $\begin{array}{l}\text { B } \\
\text { (row } 1 \text { - row2) }\end{array}$ & $\begin{array}{l}0.045 \\
(33 \%)\end{array}$ & $\begin{array}{l}0.112 \\
(39 \%)\end{array}$ & $\begin{array}{l}0.056 \\
(33 \%)\end{array}$ & $\begin{array}{l}0.055 \\
(47 \%)\end{array}$ \\
\hline $\begin{array}{l}X \\
\text { (row } 2-\text { row } 3 \text { ) }\end{array}$ & $\begin{array}{l}-0.024 \\
-(18 \%)\end{array}$ & $\begin{array}{l}-0.042 \\
-(15 \%)\end{array}$ & $\begin{array}{l}-0.041 \\
-(24 \%)\end{array}$ & $\begin{array}{l}-0.001 \\
-(1 \%)\end{array}$ \\
\hline \multirow[t]{3}{*}{$\begin{array}{l}\text { Residual (unexplained) } \\
\text { (row } 3 \text { - row 4) }\end{array}$} & $\begin{array}{l}0.113 \\
(85 \%)\end{array}$ & $\begin{array}{l}0.218 \\
(76 \%)\end{array}$ & $\begin{array}{l}0.155 \\
(91 \%)\end{array}$ & $\begin{array}{l}0.063 \\
(54 \%)\end{array}$ \\
\hline & \multicolumn{4}{|c|}{ Women } \\
\hline & Std. Dev. & $10-90$ & $10-50$ & $50-90$ \\
\hline 1) 2003 & 0.542 & 1.168 & 0.357 & 0.811 \\
\hline 2) 2003 with $1986 \mathrm{~B}$ & 0.519 & 1.175 & 0.431 & 0.744 \\
\hline 3) 2003 with $1986 \mathrm{~B} \& \mathrm{X}$ & 0.534 & 1.206 & 0.474 & 0.732 \\
\hline 4) 1986 & 0.445 & 1.076 & 0.470 & 0.606 \\
\hline 5) 2003 - 1986 Difference & 0.097 & 0.138 & -0.113 & 0.251 \\
\hline \multicolumn{5}{|l|}{ Effect of: } \\
\hline B & 0.023 & -0.007 & -0.074 & 0.067 \\
\hline (row 1 - row2) & $(24 \%)$ & $-(5 \%)$ & $-(65 \%)$ & $(26 \%)$ \\
\hline$x$ & -0.015 & -0.031 & -0.043 & 0.013 \\
\hline (row 2 - row 3 ) & $-(15 \%)$ & $-(22 \%)$ & $-(38 \%)$ & $(5 \%)$ \\
\hline $\begin{array}{l}\text { Residual (unexplained) } \\
\text { (row } 3 \text { - row 4) }\end{array}$ & $\begin{array}{l}0.089 \\
(91 \%)\end{array}$ & $\begin{array}{l}0.130 \\
(94 \%)\end{array}$ & $\begin{array}{c}0.004 \\
(4 \%)\end{array}$ & $\begin{array}{l}0.126 \\
(50 \%)\end{array}$ \\
\hline
\end{tabular}


Table 5: Reverse Order Decomposition of Changes in Inequality for Men and Women

\begin{tabular}{|c|c|c|c|c|}
\hline & \multicolumn{4}{|c|}{ Men } \\
\hline & Std. Dev. & $10-90$ & $10-50$ & $50-90$ \\
\hline 1) 2003 & 0.625 & 1.540 & 0.758 & 0.783 \\
\hline 2) 2003 with $1986 X$ & 0.665 & 1.609 & 0.762 & 0.847 \\
\hline 3) 2003 with $1986 \mathrm{~B} \& \mathrm{X}$ & 0.605 & 1.471 & 0.742 & 0.728 \\
\hline 4) 1986 & 0.492 & 1.253 & 0.588 & 0.665 \\
\hline 5) 2003 - 1986 Difference & 0.133 & 0.288 & 0.170 & 0.118 \\
\hline \multicolumn{5}{|l|}{ Effect of: } \\
\hline$x$ & -0.039 & -0.069 & -0.004 & -0.065 \\
\hline (row 1 - row2) & $-(29 \%)$ & $-(24 \%)$ & $-(3 \%)$ & $-(55 \%)$ \\
\hline B & 0.060 & 0.139 & 0.020 & 0.119 \\
\hline (row 2 - row 3 ) & $(45 \%)$ & $(48 \%)$ & $(12 \%)$ & $(101 \%)$ \\
\hline \multirow{4}{*}{$\begin{array}{l}\text { Residual (unexplained) } \\
\text { (row } 3 \text { - row 4) }\end{array}$} & 0.113 & 0.218 & 0.155 & 0.063 \\
\hline & $(85 \%)$ & $(76 \%)$ & $(91 \%)$ & $(54 \%)$ \\
\hline & \multicolumn{4}{|c|}{ Women } \\
\hline & Std. Dev. & $10-90$ & $10-50$ & $50-90$ \\
\hline 1) 2003 & 0.542 & 1.168 & 0.357 & 0.811 \\
\hline 2) 2003 with $1986 x$ & 0.569 & 1.288 & 0.511 & 0.777 \\
\hline 3) 2003 with $1986 \mathrm{~B} \& \mathrm{X}$ & 0.534 & 1.206 & 0.474 & 0.732 \\
\hline 4) 1986 & 0.445 & 1.076 & 0.470 & 0.606 \\
\hline 5) 2003 - 1986 Difference & 0.097 & 0.138 & -0.113 & 0.251 \\
\hline \multicolumn{5}{|l|}{ Effect of: } \\
\hline$x$ & -0.027 & -0.120 & -0.154 & 0.034 \\
\hline (row 1 - row2) & $-(27 \%)$ & $-(87 \%)$ & $-(136 \%)$ & $(13 \%)$ \\
\hline B & 0.035 & 0.082 & 0.037 & 0.045 \\
\hline (row 2 - row 3 ) & $(36 \%)$ & $(60 \%)$ & $(33 \%)$ & $(18 \%)$ \\
\hline $\begin{array}{l}\text { Residual (unexplained) } \\
\text { (row } 3 \text { - row 4) }\end{array}$ & $\begin{array}{l}0.089 \\
(91 \%)\end{array}$ & $\begin{array}{l}0.130 \\
(94 \%)\end{array}$ & $\begin{array}{c}0.004 \\
(4 \%)\end{array}$ & $\begin{array}{l}0.126 \\
(50 \%)\end{array}$ \\
\hline
\end{tabular}


Table 6: Logit Models

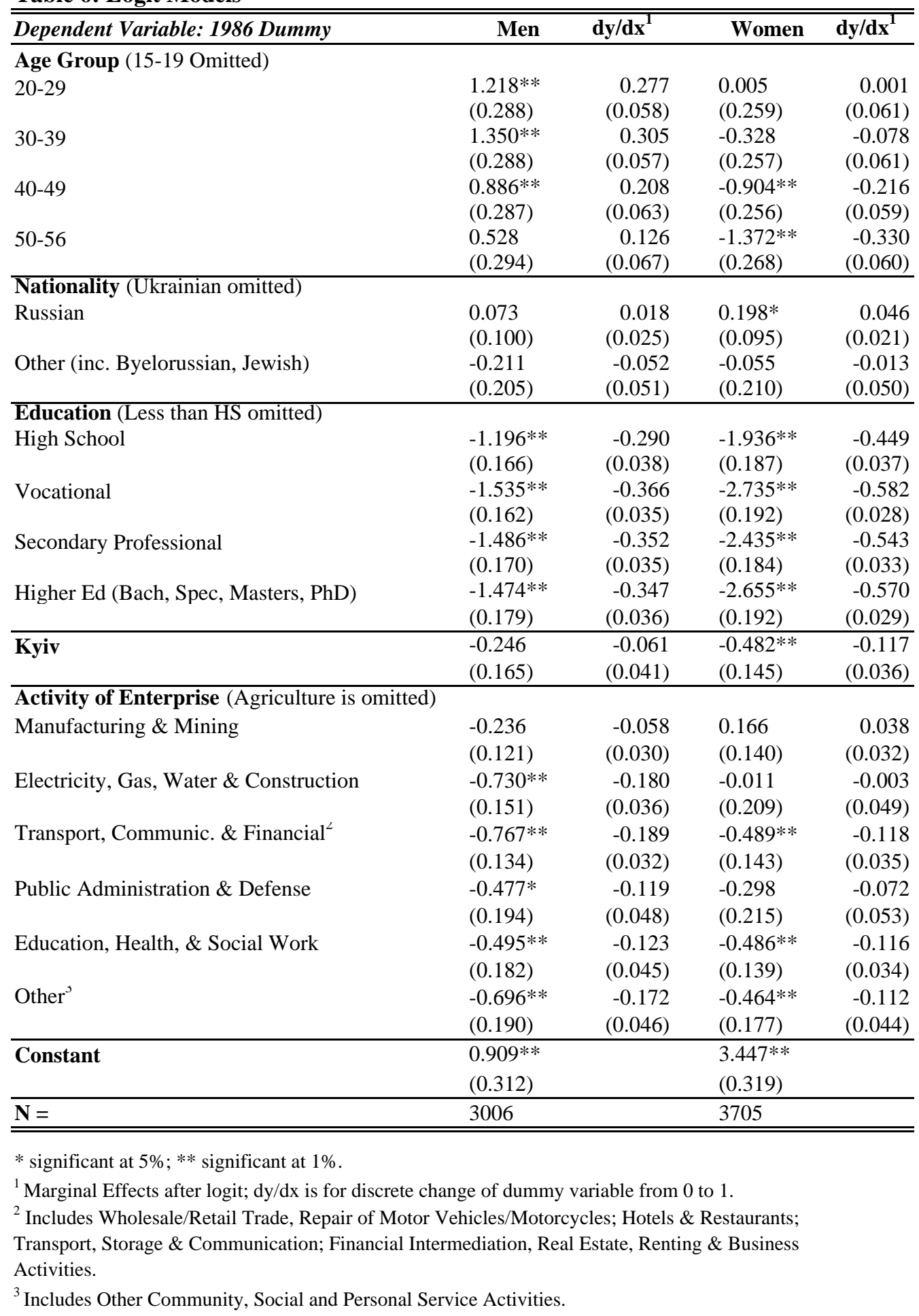


Table 7: Difference in Log Wage Regression Coefficients, 2003-

1986

\begin{tabular}{|c|c|c|}
\hline & Men & Women \\
\hline \multicolumn{3}{|l|}{ Age Group (15-19 Omitted) } \\
\hline $20-29$ & -0.019 & $0.231 *$ \\
\hline 30-39 & -0.022 & $0.192^{\#}$ \\
\hline $40-49$ & 0.005 & $0.249 *$ \\
\hline $50-56$ & -0.067 & 0.150 \\
\hline \multicolumn{3}{|l|}{ Nationality (Ukrainian omitted) } \\
\hline Russian & -0.046 & $0.106 *$ \\
\hline Other (inc. Byelorussian, Jewish) & 0.169 & -0.007 \\
\hline \multicolumn{3}{|l|}{ Education (Less than HS omitted) } \\
\hline High School & -0.044 & 0.109 \\
\hline Vocational & -0.078 & 0.059 \\
\hline Secondary Professional & -0.022 & $0.137^{\#}$ \\
\hline Higher Ed (Bach, Spec, Masters, PhD) & 0.140 & 0.116 \\
\hline$\overline{\text { Kyiv }}$ & 0.106 & $0.181 *$ \\
\hline \multicolumn{3}{|c|}{ Activity of Enterprise (Agriculture is omitted) } \\
\hline Manufacturing \& Mining & $0.347 *$ & $0.116 *$ \\
\hline Electricity, Gas, Water \& Construction & $0.395 *$ & $0.200 *$ \\
\hline Transport, Communic. \& Financial $^{1}$ & $0.480 *$ & $0.244 *$ \\
\hline Public Administration \& Defense & $0.397 *$ & $0.275 *$ \\
\hline Education, Health, \& Social Work & $0.244 *$ & $0.097^{\#}$ \\
\hline Other $^{2}$ & $0.318 *$ & $0.151 *$ \\
\hline Constant & $-0.390 *$ & $-0.515 *$ \\
\hline \multicolumn{3}{|l|}{$\#$ significant at $10 \%$; * significant at $5 \%$. } \\
\hline \multicolumn{3}{|c|}{$\begin{array}{l}{ }^{1} \text { Includes Wholesale/Retail Trade, Repair of Motor Vehicles/Motorcycles; Hotels \& } \\
\text { Restaurants; Transport, Storage \& Communication; Financial Intermediation, Real } \\
\text { Estate, Renting \& Business Activities. }\end{array}$} \\
\hline
\end{tabular}




\section{Figure 1. Ukraine's Macroeconomic Trends}

\section{Figure 1a.}

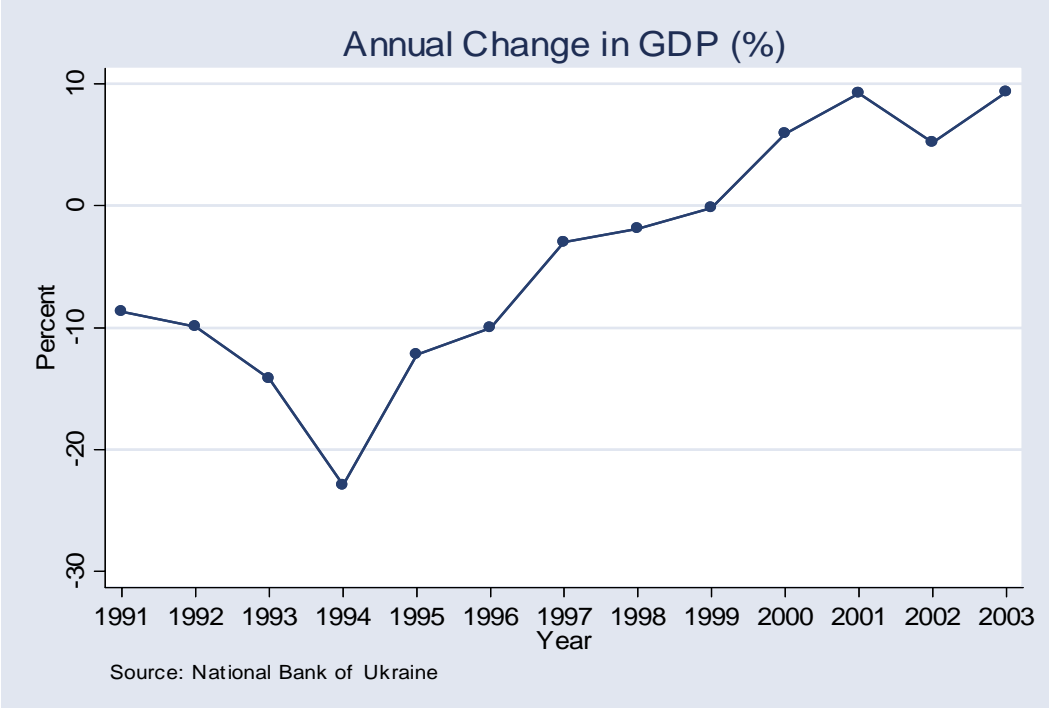

\section{Figure 1c.}

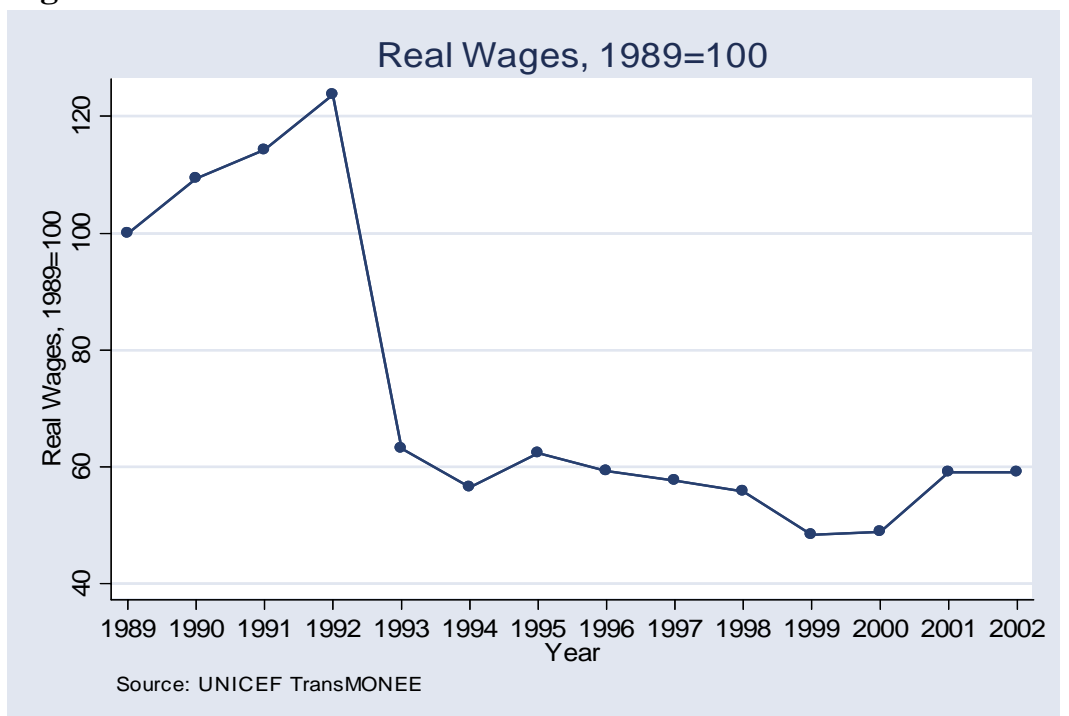

\section{Figure 1b.}

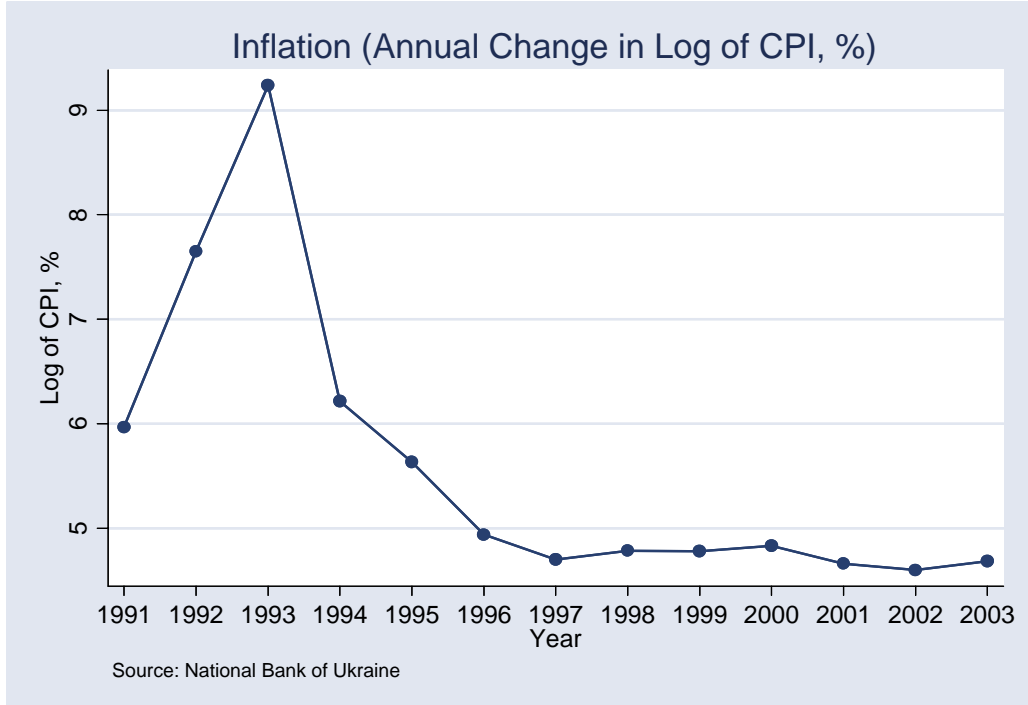

\section{Figure 1d.}

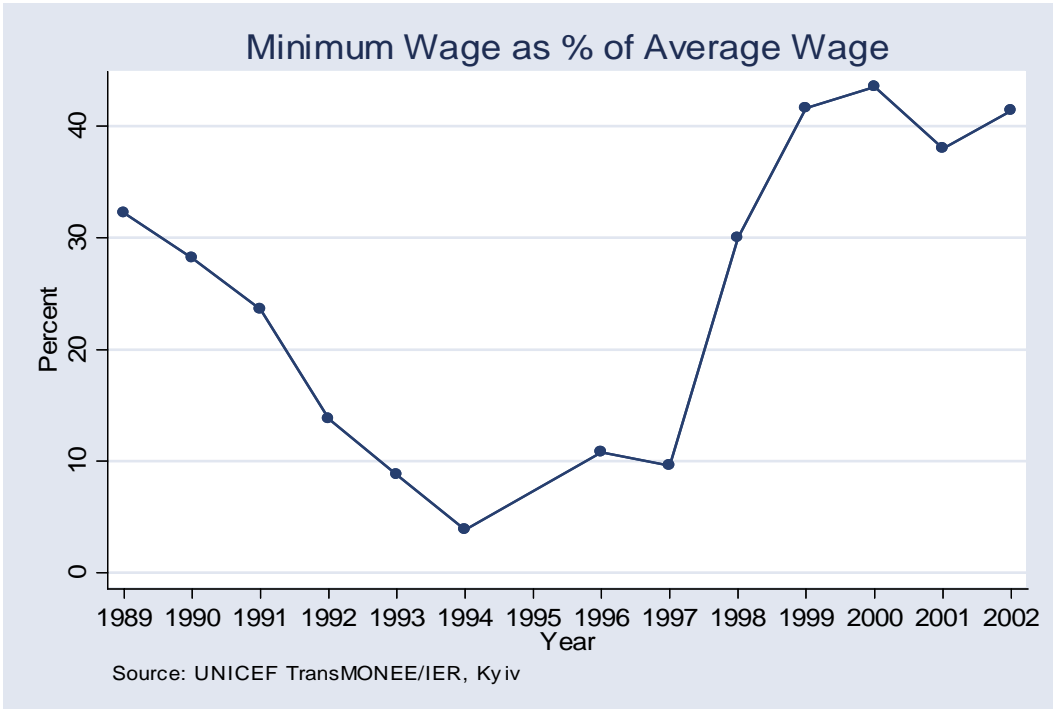


Figure 2: Kernel Density Estimates of Log of Real Wages, 1986 and 2003

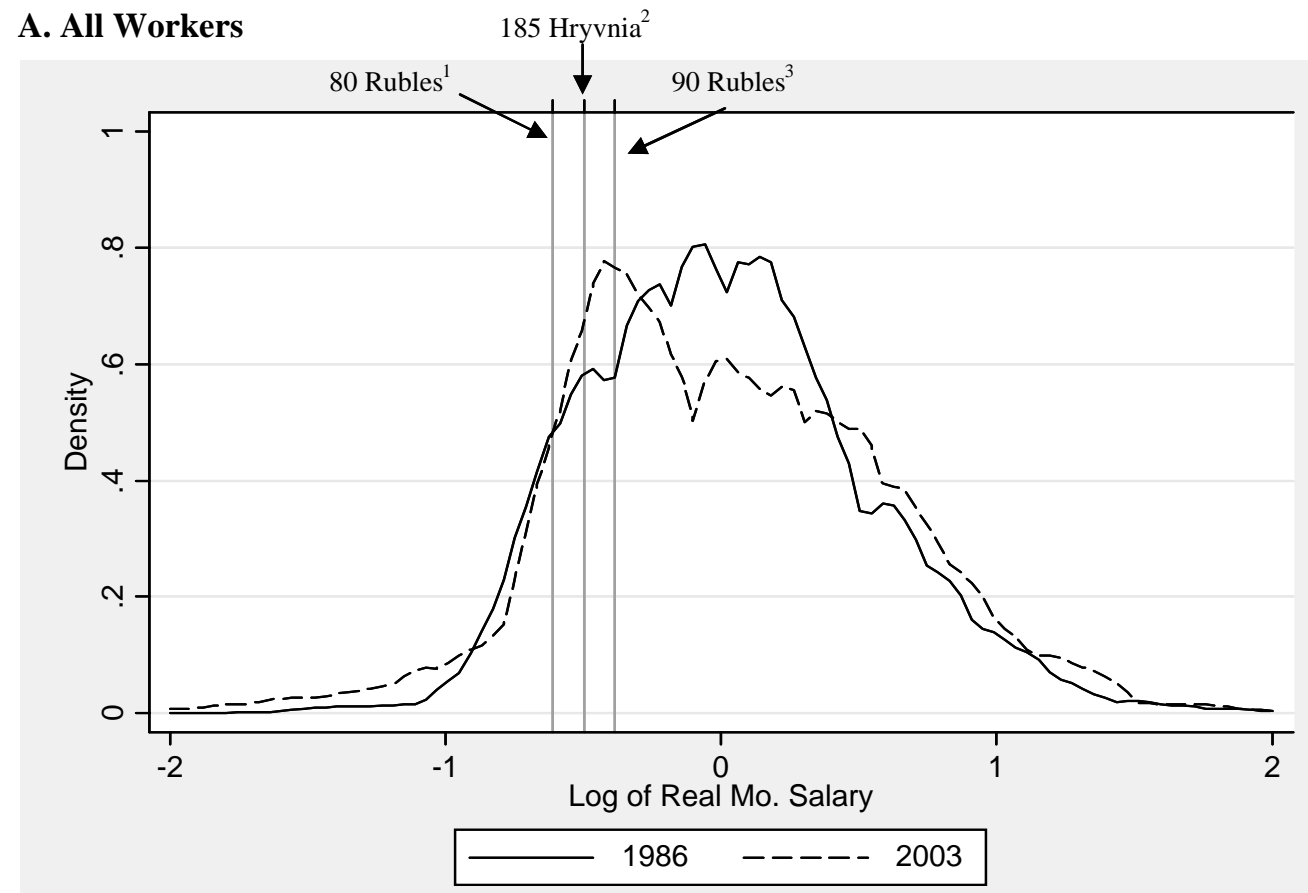

\section{B. Men and Women}

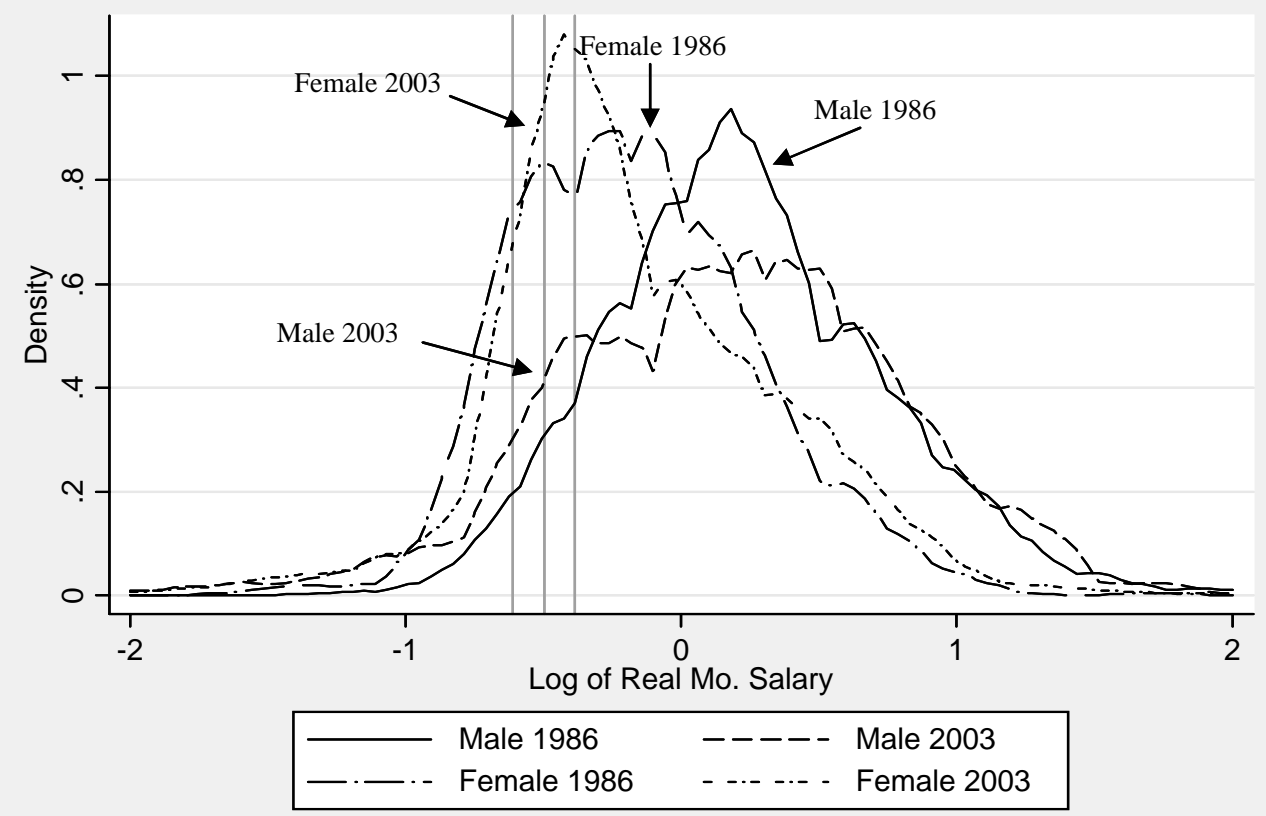

${ }^{1} 1985$ Minimum Wage Salary (80 Roubles $=$ Log value of -0.613$)$.

${ }^{2} 2003$ Minimum Wage (185 Hryvnia = Log value of -0.495 ).

${ }^{3} 90$ Roubles $=$ Log value of -0.384 .

Note: Wages in each year are rescaled so that the mean log wage is zero. 
Figure 3: Kernel Density Estimates, Actual and Counterfactual (with B and X separately)

3a) Men: [2003 with 1986 B] \& [2003 $]^{1}$

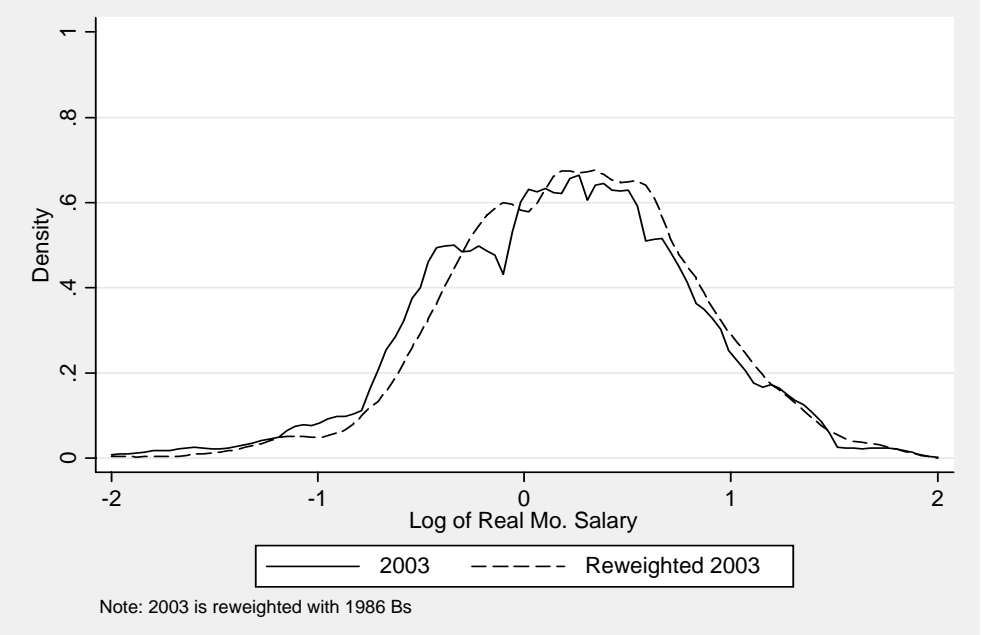

3c) Women: [2003 with $1986 \mathrm{~B}] \&[2003]^{1}$

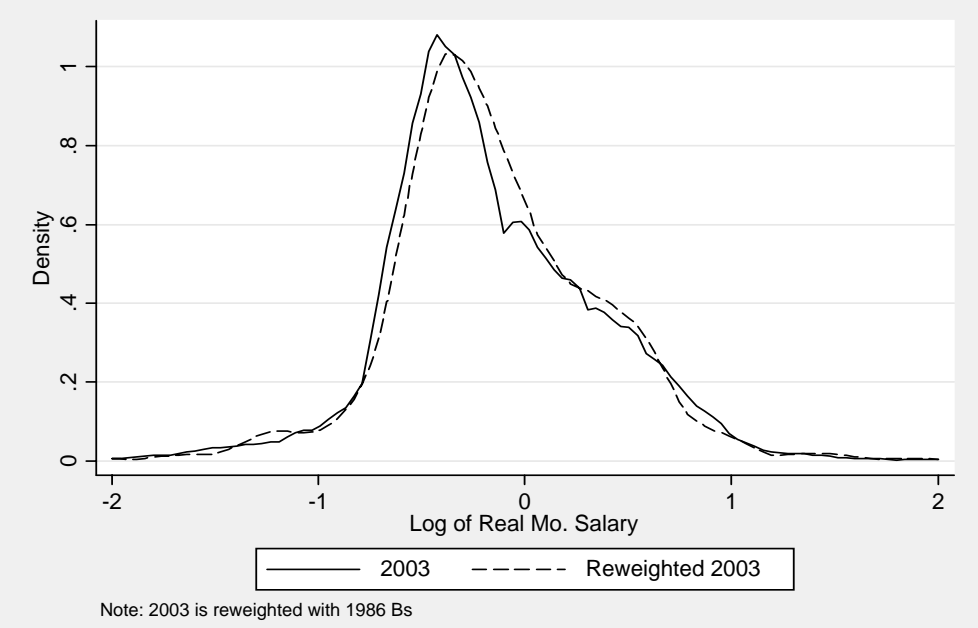

${ }^{1}$ Counterfactual is constructed with $y_{\text {io } 3}^{a}$ and $w_{i}$

${ }^{2}$ Counterfactual is constructed with $y_{\text {io } 3}$ and $\quad w_{i}^{a}$ 3b) Men: [2003 with $1986 \mathrm{X}$ ] \& [2003] ${ }^{2}$

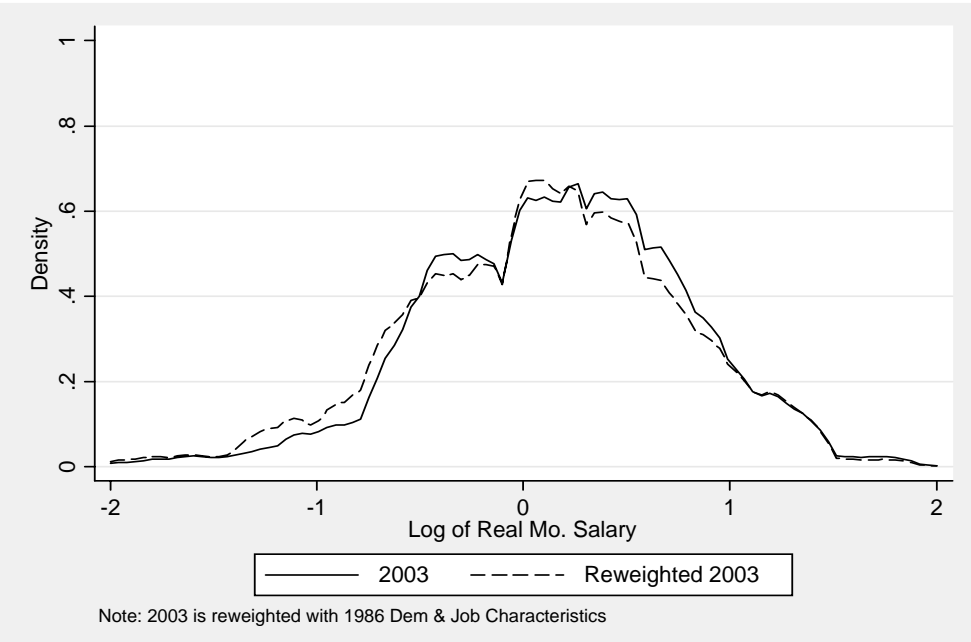

3d) Women: [2003 with $1986 \mathrm{X}] \&[2003]^{2}$

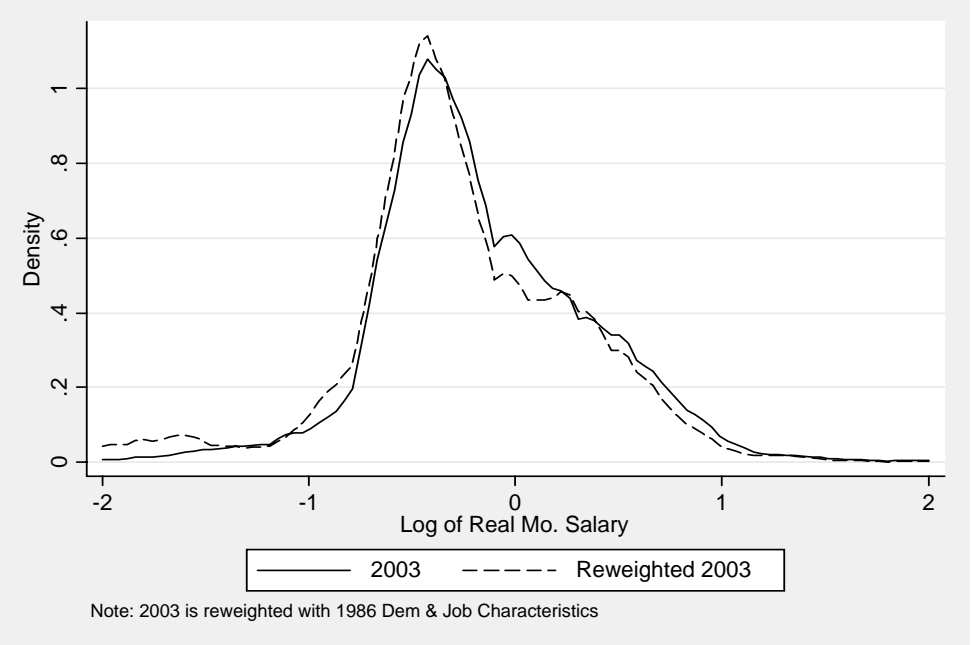




\begin{tabular}{|c|c|c|c|c|c|c|c|c|c|c|c|c|}
\hline & \multirow{2}{*}{\multicolumn{2}{|c|}{$\begin{array}{c}\text { Total Sample, } 15 \\
56 \\
\text { (a) }\end{array}$}} & \multirow{2}{*}{\multicolumn{2}{|c|}{$\begin{array}{c}\begin{array}{c}\text { Analytical } \\
\text { Sample }\end{array} \\
\text { Employed } \mathrm{FT}^{1}\end{array}$}} & \multirow{2}{*}{\multicolumn{2}{|c|}{ 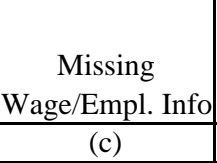 }} & \multirow{2}{*}{\multicolumn{2}{|c|}{$\frac{\text { Employed PT }}{\text { (d) }}$}} & \multirow{2}{*}{\multicolumn{2}{|c|}{$\begin{array}{c}\begin{array}{c}\text { Unemployed } \\
\text { (Job-Seeking) }\end{array} \\
\text { (e) }\end{array}$}} & \multirow{2}{*}{\multicolumn{2}{|c|}{$\frac{\text { Out of LF }}{\text { (f) }}$}} \\
\hline & & & & & & & & & & & & \\
\hline & 86 & 03 & 86 & 03 & 86 & 03 & 86 & 03 & 86 & 03 & 86 & 03 \\
\hline \multicolumn{13}{|l|}{ MEN } \\
\hline $\begin{array}{l}\text { Observations } \\
\% \text { of Total Sample, age }\end{array}$ & 2451 & 2843 & 1684 & 1355 & 337 & 307 & 26 & 110 & 22 & 410 & 382 & 661 \\
\hline $\begin{array}{l}\text { 15-56 } \\
\text { Age }\end{array}$ & $100 \%$ & $100 \%$ & $69 \%$ & $48 \%$ & $14 \%$ & $11 \%$ & $1 \%$ & $4 \%$ & $1 \%$ & $14 \%$ & $16 \%$ & $23 \%$ \\
\hline $15-19$ & 17.6 & 16.1 & 2.2 & 2.9 & 5.1 & 4.0 & 0.0 & 9.6 & 56.5 & 10.2 & 71.0 & 52.4 \\
\hline 20-29 & 32.9 & 24.2 & 36.2 & 27.4 & 34.8 & 27.4 & 45.5 & 18.9 & 29.8 & 30.0 & 21.4 & 13.8 \\
\hline 30-39 & 24.3 & 20.9 & 31.3 & 24.7 & 27.6 & 26.3 & 40.7 & 21.3 & 10.4 & 24.7 & 1.0 & 8.4 \\
\hline $40-49$ & 14.8 & 23.7 & 18.6 & 28.4 & 19.4 & 27.7 & 13.8 & 31.1 & 3.3 & 24.3 & 1.0 & 11.2 \\
\hline $50-56$ & 10.3 & 15.1 & 11.7 & 16.5 & 13.2 & 14.7 & 0.0 & 19.2 & 0.0 & 10.9 & 5.6 & 14.3 \\
\hline \multicolumn{13}{|l|}{ Education Levels } \\
\hline Less than High School & 20.4 & 15.0 & 12.7 & 4.8 & 17.1 & 7.7 & 5.9 & 7.5 & 35.2 & 9.0 & 45.9 & 43.4 \\
\hline High School & 27.4 & 24.3 & 26.9 & 22.7 & 24.2 & 26.2 & 38.0 & 20.4 & 22.1 & 25.7 & 30.6 & 26.5 \\
\hline Vocational & 26.8 & 30.3 & 29.4 & 33.4 & 28.4 & 30.3 & 32.1 & 37.4 & 37.8 & 41.3 & 17.0 & 16.4 \\
\hline Secondary Professional & 14.9 & 17.4 & 18.0 & 21.9 & 16.4 & 18.3 & 14.2 & 16.3 & 2.3 & 16.1 & 5.4 & 8.8 \\
\hline Higher Education & 10.5 & 13.1 & 13.1 & 17.2 & 13.8 & 17.4 & 9.8 & 18.4 & 2.6 & 8.0 & 1.2 & 4.9 \\
\hline \multicolumn{13}{|l|}{ Nationality } \\
\hline Ukrainian & 78.5 & 79.2 & 78.2 & 77.9 & 78.2 & 79.2 & 97.5 & 83.0 & 78.6 & 79.2 & 78.5 & 81.4 \\
\hline Russian & 18.1 & 16.7 & 18.3 & 17.5 & 17.5 & 16.4 & 2.5 & 11.4 & 13.5 & 18.3 & 19.0 & 14.9 \\
\hline Other (Including & & & & & & & & & & & & \\
\hline Belorussian, Jewish) & 3.5 & 4.1 & 3.6 & 4.6 & 4.3 & 4.4 & 0.0 & 5.5 & 8.0 & 2.4 & 2.6 & 3.7 \\
\hline \multicolumn{13}{|l|}{ Marital Status } \\
\hline Unmarried & 35.2 & 43.1 & 19.0 & 28.7 & 21.5 & 31.9 & 19.6 & 35.7 & 88.6 & 47.9 & 90.6 & 74.8 \\
\hline Married & 64.8 & 56.9 & 81.0 & 71.3 & 78.5 & 68.1 & 80.4 & 64.3 & 11.4 & 52.1 & 9.4 & 25.2 \\
\hline \multicolumn{13}{|l|}{ WOMEN } \\
\hline $\begin{array}{l}\text { Observations } \\
\% \text { of Total Sample, age }\end{array}$ & 3458 & 3682 & 2263 & 1494 & 521 & 178 & 47 & 225 & 17 & 415 & 610 & 1370 \\
\hline $\begin{array}{l}\text { 15-56 } \\
\text { Age }\end{array}$ & $100 \%$ & $100 \%$ & $65 \%$ & $41 \%$ & $15 \%$ & $5 \%$ & $1 \%$ & $6 \%$ & $0.5 \%$ & $11 \%$ & $18 \%$ & $37 \%$ \\
\hline $15-19$ & 13.4 & 13.1 & 3.5 & 1.5 & 3.6 & 3.0 & 2.5 & 3.1 & 30.6 & 8.2 & 51.0 & 31.0 \\
\hline $20-29$ & 26.9 & 22.7 & 27.9 & 19.6 & 26.5 & 19.6 & 25.4 & 18.0 & 48.4 & 31.5 & 24.0 & 24.5 \\
\hline $30-39$ & 26.4 & 20.9 & 30.6 & 26.0 & 31.4 & 26.6 & 51.8 & 27.2 & 6.8 & 23.1 & 8.8 & 12.5 \\
\hline $40-49$ & 19.9 & 26.6 & 24.7 & 34.9 & 20.7 & 38.8 & 17.6 & 34.6 & 14.2 & 25.5 & 5.1 & 14.6 \\
\hline $50-56$ & 13.4 & 16.8 & 13.4 & 18.0 & 17.8 & 12.1 & 2.8 & 17.1 & 0.0 & 11.8 & 11.1 & 17.4 \\
\hline \multicolumn{13}{|l|}{ Education Levels } \\
\hline Less than High School & 22.8 & 12.2 & 17.2 & 2.6 & 21.4 & 7.0 & 14.6 & 4.9 & 28.0 & 7.4 & 41.1 & 26.7 \\
\hline High School & 26.6 & 24.7 & 25.8 & 18.5 & 23.3 & 25.0 & 17.0 & 19.1 & 24.1 & 25.7 & 31.9 & 32.2 \\
\hline Vocational & 15.6 & 20.6 & 16.1 & 22.1 & 16.5 & 23.2 & 24.8 & 19.5 & 38.9 & 26.2 & 12.1 & 17.0 \\
\hline Secondary Professional & 22.9 & 26.7 & 26.5 & 33.3 & 24.0 & 25.8 & 27.9 & 27.0 & 6.5 & 29.7 & 11.1 & 18.3 \\
\hline Higher Education & 12.2 & 15.8 & 14.3 & 23.5 & 14.7 & 19.1 & 15.7 & 29.6 & 2.6 & 11.1 & 3.9 & 5.9 \\
\hline \multicolumn{13}{|l|}{ Nationality } \\
\hline Ukrainian & 77.8 & 78.5 & 77.6 & 78.5 & 80.1 & 79.5 & 69.3 & 80.5 & 56.4 & 74.4 & 77.3 & 79.2 \\
\hline Russian & 19.0 & 17.6 & 19.2 & 18.4 & 16.8 & 17.1 & 30.7 & 16.3 & 43.6 & 20.3 & 18.9 & 16.1 \\
\hline $\begin{array}{l}\text { Other (Including } \\
\text { Belorussian, Jewish) }\end{array}$ & 3.3 & 4.0 & 3.2 & 3.2 & 3.1 & 3.4 & & 3.2 & 0.0 & 5.3 & 3.8 & 4.7 \\
\hline \multicolumn{13}{|l|}{ Marital Status } \\
\hline Unmarried & 26.3 & 39.3 & 18.4 & 33.9 & 21.2 & 33.7 & 19.0 & 29.8 & 55.6 & 44.4 & 53.8 & 46.7 \\
\hline Married & 73.7 & 60.7 & 81.6 & 66.1 & 78.8 & 66.3 & 81.0 & 70.2 & 44.4 & 55.6 & 46.2 & 53.3 \\
\hline
\end{tabular}

${ }^{1}$ For 1986, FT means they did not report working 'always' or 'sometimes' part-time; For 2003, FT means reporting between 40 and 80 hours/week, or 30-40 hours/week if it is considered FT at that job. 
Table A2: Log-Wage Regressions

\begin{tabular}{|c|c|c|c|c|}
\hline & $\begin{array}{c}1986 \\
\text { Males }\end{array}$ & $\begin{array}{c}2003 \\
\text { Males }\end{array}$ & $\begin{array}{c}1986 \\
\text { Females }\end{array}$ & $\begin{array}{c}2003 \\
\text { Females }\end{array}$ \\
\hline \multicolumn{5}{|l|}{ Age Group (15-19 Omitted) } \\
\hline $20-29$ & $\begin{array}{l}0.190^{*} \\
(0.078)\end{array}$ & $\begin{array}{l}0.175 \\
(0.096)\end{array}$ & $\begin{array}{l}0.029 \\
(0.050)\end{array}$ & $\begin{array}{l}0.266^{*} \\
(0.110)\end{array}$ \\
\hline 30-39 & $\begin{array}{l}0.238 * * \\
(0.078)\end{array}$ & $\begin{array}{l}0.217^{*} \\
(0.097)\end{array}$ & $\begin{array}{l}0.087 \\
(0.050)\end{array}$ & $\begin{array}{l}0.286^{* *} \\
(0.109)\end{array}$ \\
\hline $40-49$ & $\begin{array}{l}0.214^{* *} \\
(0.080)\end{array}$ & $\begin{array}{l}0.221^{*} \\
(0.096)\end{array}$ & $\begin{array}{l}0.068 \\
(0.051)\end{array}$ & $\begin{array}{l}0.327^{* *} \\
(0.109)\end{array}$ \\
\hline $50-56$ & $\begin{array}{l}0.205^{*} \\
(0.083)\end{array}$ & $\begin{array}{l}0.139 \\
(0.099)\end{array}$ & $\begin{array}{l}0.112^{*} \\
(0.055)\end{array}$ & $\begin{array}{l}0.271^{*} \\
(0.111)\end{array}$ \\
\hline \multicolumn{5}{|l|}{ Nationality (Ukrainian omitted) } \\
\hline Russian & $\begin{array}{l}0.092 * * \\
(0.029)\end{array}$ & $\begin{array}{l}0.040 \\
(0.041)\end{array}$ & $\begin{array}{l}0.025 \\
(0.023)\end{array}$ & $\begin{array}{l}0.135 * * \\
(0.034)\end{array}$ \\
\hline Other (inc. Byelorussian, Jewish) & $\begin{array}{l}-0.064 \\
(0.061)\end{array}$ & $\begin{array}{l}0.109 \\
(0.073)\end{array}$ & $\begin{array}{l}0.011 \\
(0.050)\end{array}$ & $\begin{array}{l}0.002 \\
(0.073)\end{array}$ \\
\hline \multicolumn{5}{|l|}{ 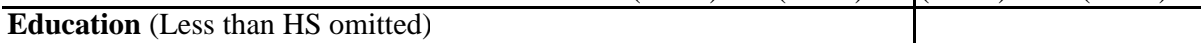 } \\
\hline High School & $\begin{array}{l}0.046 \\
(0.042)\end{array}$ & $\begin{array}{l}0.001 \\
(0.078)\end{array}$ & $\begin{array}{l}0.079 * * \\
(0.030)\end{array}$ & $\begin{array}{l}0.183 * \\
(0.086)\end{array}$ \\
\hline Vocational & $\begin{array}{l}0.111^{* *} \\
(0.040)\end{array}$ & $\begin{array}{l}0.031 \\
(0.076)\end{array}$ & $\begin{array}{l}0.133^{* *} \\
(0.034)\end{array}$ & $\begin{array}{l}0.184^{*} \\
(0.085)\end{array}$ \\
\hline Secondary Professional & $\begin{array}{l}0.194^{* *} \\
(0.044)\end{array}$ & $\begin{array}{l}0.173^{*} \\
(0.079)\end{array}$ & $\begin{array}{l}0.133^{* *} \\
(0.030)\end{array}$ & $\begin{array}{l}0.267 * * \\
(0.083)\end{array}$ \\
\hline Higher Ed (Bach, Spec, Masters, PhD) & $\begin{array}{l}0.246^{* *} \\
(0.047) \\
\end{array}$ & $\begin{array}{l}0.388^{* *} \\
(0.082) \\
\end{array}$ & $\begin{array}{l}0.396^{* *} \\
(0.035)\end{array}$ & $\begin{array}{l}0.507^{* *} \\
(0.085) \\
\end{array}$ \\
\hline$\overline{\text { Kyiv }}$ & $\begin{array}{l}0.102^{*} \\
(0.047)\end{array}$ & $\begin{array}{l}0.213^{* *} \\
(0.056)\end{array}$ & $\begin{array}{l}0.115^{* *} \\
(0.037)\end{array}$ & $\begin{array}{l}0.296 * * \\
(0.044)\end{array}$ \\
\hline \multicolumn{5}{|c|}{ Activity of Enterprise (Agriculture is omitted) } \\
\hline Manufacturing \& Mining & $\begin{array}{l}0.392 * * \\
(0.032)\end{array}$ & $\begin{array}{l}0.738 * * \\
(0.054)\end{array}$ & $\begin{array}{l}0.247 * * \\
(0.030)\end{array}$ & $\begin{array}{l}0.369 * * \\
(0.056)\end{array}$ \\
\hline Electricity, Gas, Water \& Construction & $\begin{array}{l}0.255^{* *} \\
(0.044)\end{array}$ & $\begin{array}{l}0.650^{* *} \\
(0.062)\end{array}$ & $\begin{array}{l}0.241^{* *} \\
(0.048)\end{array}$ & $\begin{array}{l}0.444 * * \\
(0.081)\end{array}$ \\
\hline Transport, Communic. \& Financial $^{1}$ & $\begin{array}{l}0.173 * * \\
(0.038)\end{array}$ & $\begin{array}{l}0.652^{* *} \\
(0.057)\end{array}$ & $\begin{array}{l}0.034 \\
(0.033)\end{array}$ & $\begin{array}{l}0.276^{* *} \\
(0.056)\end{array}$ \\
\hline Public Administration \& Defense & $\begin{array}{l}0.287 * * \\
(0.054)\end{array}$ & $\begin{array}{l}0.684^{* *} \\
(0.080)\end{array}$ & $\begin{array}{l}-0.013 \\
(0.054)\end{array}$ & $\begin{array}{l}0.259 * * \\
(0.081)\end{array}$ \\
\hline Education, Health, \& Social Work & $\begin{array}{l}-0.133^{*} \\
(0.055)\end{array}$ & $\begin{array}{l}0.110 \\
(0.074)\end{array}$ & $\mid \begin{array}{l}-0.110^{* *} \\
(0.032)\end{array}$ & $\begin{array}{l}-0.008 \\
(0.054)\end{array}$ \\
\hline Other $^{2}$ & $\begin{array}{l}0.035 \\
(0.056)\end{array}$ & $\begin{array}{l}0.350 * * \\
(0.077)\end{array}$ & $\begin{array}{l}0.016 \\
(0.043)\end{array}$ & $\begin{array}{l}0.170^{* *} \\
(0.065)\end{array}$ \\
\hline \multicolumn{5}{|l|}{ Month (April omitted) } \\
\hline May & & $\begin{array}{l}-0.045 \\
(0.034)\end{array}$ & & $\begin{array}{l}0.004 \\
(0.028)\end{array}$ \\
\hline June & & $\begin{array}{l}-0.029 \\
(0.057)\end{array}$ & & $\begin{array}{l}0.014 \\
(0.051)\end{array}$ \\
\hline July & & $\begin{array}{l}0.038 \\
(0.125)\end{array}$ & & $\begin{array}{l}0.271^{*} \\
(0.112)\end{array}$ \\
\hline Constant & $\begin{array}{l}-0.327^{* *} \\
(0.084)\end{array}$ & $\begin{array}{l}-0.690^{* *} \\
(0.116)\end{array}$ & $\begin{array}{l}-0.450^{* *} \\
(0.057)\end{array}$ & $\begin{array}{l}-0.979 * * \\
(0.138)\end{array}$ \\
\hline$\overline{\mathbf{N}}=$ & 1666 & 1340 & 2230 & 1475 \\
\hline R-Squared = & 0.17 & 0.23 & 0.15 & 0.19 \\
\hline
\end{tabular}

* significant at $5 \%$; ** significant at $1 \%$.

${ }^{1}$ Includes Wholesale/Retail Trade, Repair of Motor Vehicles/Motorcycles; Hotels \&

Restaurants; Transport, Storage \& Communication; Financial Intermediation, Real Estate, Renting \& Business Activities.

${ }^{3}$ Includes Other Community, Social and Personal Service Activities.

Note: Regressions run using sample weights. 


\section{Figure A1: Comparison of Actual and Contractual Log Salary}

A. Non-Zero Difference in "Contractual" and "Actual" Log of Salary

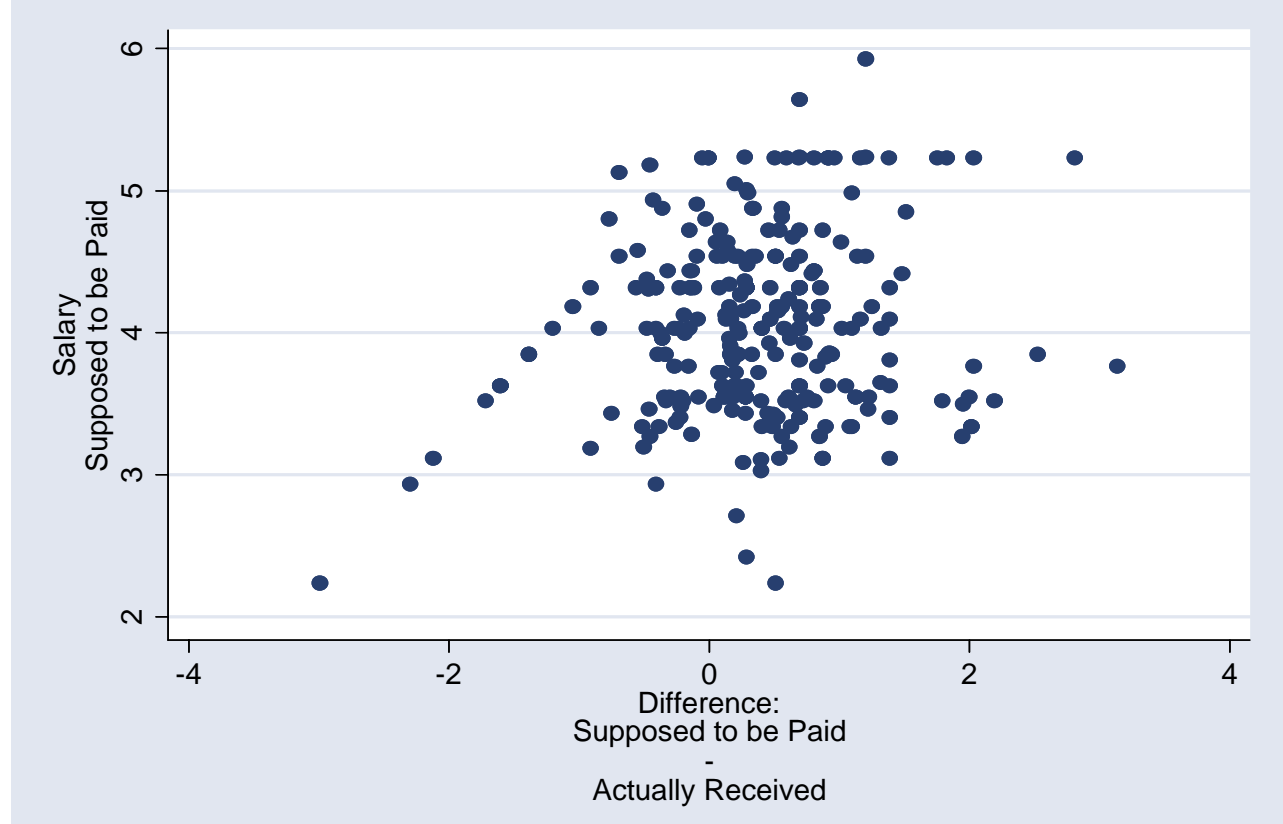

B. Distribution of Actual and Contractual Log Salary

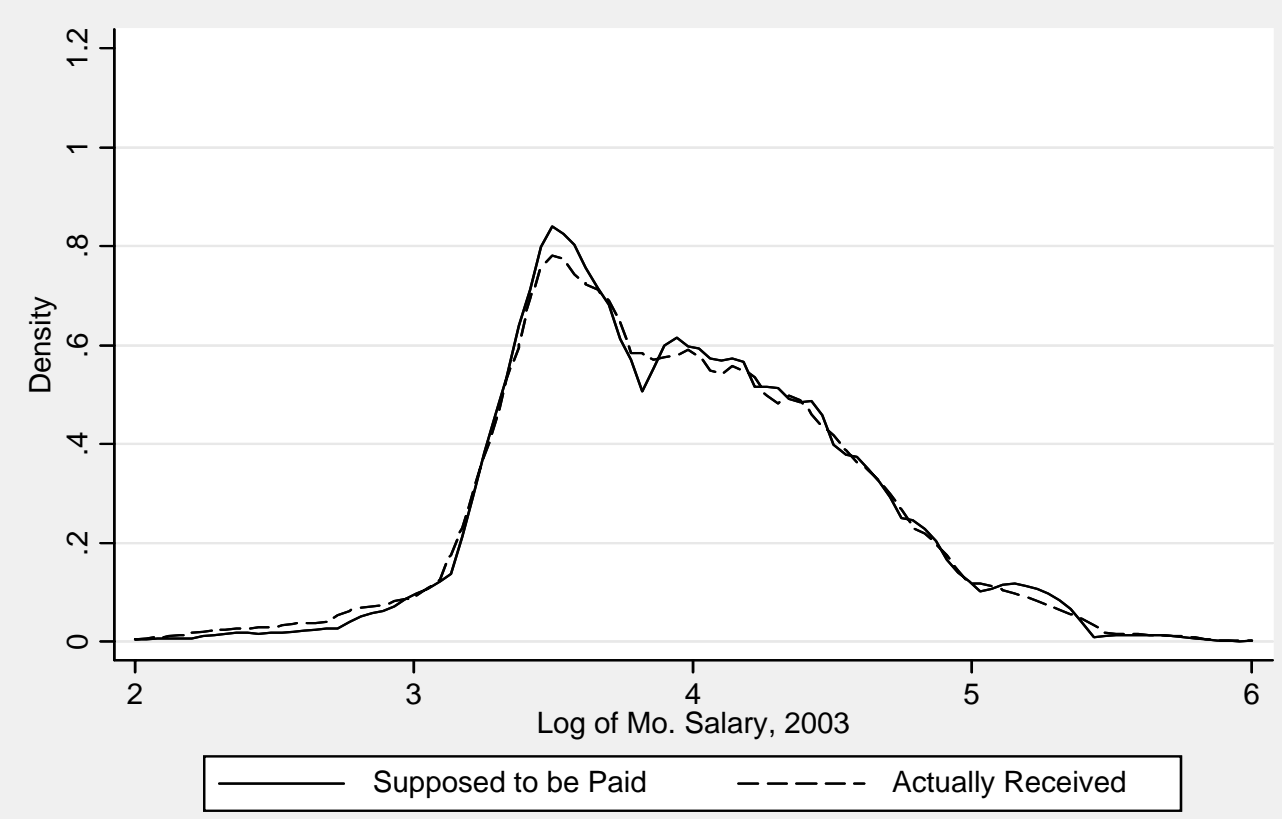

